\title{
Contributions and Risks of Artificial Intelligence (AI) in Building Smarter Cities: Insights from a Systematic Review of the Literature
}

\author{
Tan Yigitcanlar ${ }^{1, *(\mathbb{C})}$, Kevin C. Desouza ${ }^{2}$, Luke Butler ${ }^{1}(\mathbb{D})$ and Farnoosh Roozkhosh ${ }^{3}(\mathbb{D}$ \\ 1 School of Built Environment, Queensland University of Technology, 2 George Street, Brisbane, QLD 4000, \\ Australia; luke.butler@hdr.qut.edu.au \\ 2 QUT Business School, Queensland University of Technology, 2 George Street, Brisbane, QLD 4000, Australia; \\ kevin.desouza@qut.edu.au \\ 3 School of Arts and Architecture, Guilan University, Persian Gulf Highway, Rasht 41998-43653, Guilan, Iran; \\ farnoosh_r@msc.guilan.ac.ir \\ * Correspondence: tan.yigitcanlar@qut.edu.au; Tel.: +61-7-3138-2418
}

Received: 24 February 2020; Accepted: 16 March 2020; Published: 20 March 2020

\begin{abstract}
Artificial intelligence (AI) is one of the most disruptive technologies of our time. Interest in the use of AI for urban innovation continues to grow. Particularly, the rise of smart cities-urban locations that are enabled by community, technology, and policy to deliver productivity, innovation, livability, wellbeing, sustainability, accessibility, good governance, and good planning-has increased the demand for AI-enabled innovations. There is, nevertheless, no scholarly work that provides a comprehensive review on the topic. This paper generates insights into how AI can contribute to the development of smarter cities. A systematic review of the literature is selected as the methodologic approach. Results are categorized under the main smart city development dimensions, i.e., economy, society, environment, and governance. The findings of the systematic review containing 93 articles disclose that: (a) AI in the context of smart cities is an emerging field of research and practice. (b) The central focus of the literature is on AI technologies, algorithms, and their current and prospective applications. (c) AI applications in the context of smart cities mainly concentrate on business efficiency, data analytics, education, energy, environmental sustainability, health, land use, security, transport, and urban management areas. (d) There is limited scholarly research investigating the risks of wider AI utilization. (e) Upcoming disruptions of AI in cities and societies have not been adequately examined. Current and potential contributions of AI to the development of smarter cities are outlined in this paper to inform scholars of prospective areas for further research.
\end{abstract}

Keywords: artificial intelligence (AI); AI technologies; AI algorithms; disruptive technology; smart city; smart urban technology; urban informatics; sustainable urban development; climate change

\section{Introduction}

There exists a strong scientific consensus that anthropogenic climate change is the biggest crisis of our time [1,2]. In a rapidly urbanizing world, climate change and the misuse and mismanagement of land and resources are triggering natural disasters and increasing their intensity [3,4]. Subsequently, cities are becoming frequently subjected to the direct or indirect impacts of natural disasters-for example, the 2019 Amazon Rainforest fires [5] and the 2020 Australian bushfires [6]. There have been numerous top-down (e.g., the Paris Agreement, Intergovernmental Panel on Climate Change, UN's Sustainable Development Goals, UN Climate Change Conferences) and bottom-up (e.g., school strikes, extinction rebellion protests, climate emergency declarations) attempts to raise awareness and develop policy actions to address the climate emergency $[7,8]$. 
These efforts provided some hope, despite the political and policy quagmires in many countries. Nevertheless, there has been no significant climate action undertaken to address the crisis. Instead, in recent years, with the advancement of the current digital revolution, a large portion of policymakers, practitioners, and scholars have increased their faith in smart urban technologies to mark a major turning point in the history of humankind [9]. This technocentric view-in solving urban and environmental problems with the aid of technology-has increased the popularity of the 'smart cities' notion [10]. These cities—also referred to as 'geographies of disruption' [11]—harness digital technologies to offer new business opportunities, shape the urban fabric, improve the quality and performance, and overcome many of the challenges confronted by urban areas [12].

The prospects of smart urban technologies range from expanding infrastructure capacity to generating new services, from reducing emissions to engaging the public, from minimizing human errors to improved decision-making, and from supporting sustainable development to improving performances of commercial enterprises and cities $[13,14]$. The most popular technologies in the context of smart cities include but are not limited to internet-of-things (IoT), autonomous vehicles (AV), bigdata, 5G, robotics, blockchain, cloud computing, 3D printing, virtual reality (VR), digital twins, and artificial intelligence (AI) [15-17]. While all these technologies are critical in transforming our cities into smarter ones, AI combined with these technologies has significant potential to address the urbanization challenges of our time [18]. Furthermore, AI is certainly seen as the most disruptive technology among them $[19,20]$.

The prospective benefits of AI for cities continue to be discussed in the literature in the context of smart cities - that are enabled by community, technology, and policy to deliver productivity, innovation, livability, wellbeing, sustainability, accessibility, as well as good governance and planning [15,21,22]. Despite the growing number of articles on the topic, there is no scholarly work that provides a comprehensive review of the growing literature. This paper organizes the literature to examine how AI can contribute to the development of smarter cities. As the methodologic approach, the study adopts a systematic literature review on the topic of 'AI and the smart city'.

\section{Conceptual and Application Background}

In broad terms, AI is defined as "machines or computers that mimic cognitive functions that humans associate with the human mind, such as learning and problem solving" [23]. In other words, $\mathrm{AI}$, where machines mimic human cognitive functions, can make decisions, think, learn and improve themselves. It was first introduced in 1956 at Dartmouth College, but development was slow until recently due to immature computational technologies. In recent times, advances in hardware, software, and networking technologies have enabled us to design, develop, and deploy AI systems at scale. The application areas of AI ranges from banking and finance to marketing and gaming, and from agriculture and healthcare to AVs and space exploration — and many more areas [24].

AI-driven computational techniques are diverse and range from rule-based systems to deep learning systems. A popular AI knowledge map was created by Corea [25]. His conceptualization brings together the AI paradigms and the AI problem domains (Figure 1). The $\mathrm{X}$-axis categories various computational paradigms and the $\mathrm{Y}$-axis outlines problem domains. Various technologies are then mapped to illustrate their potential value. For example, rule-based systems (e.g., expert systems, robotic process automation) that are logic-driven knowledge engines, which are common in urban systems, are often used to capture and automate structured workflows. 


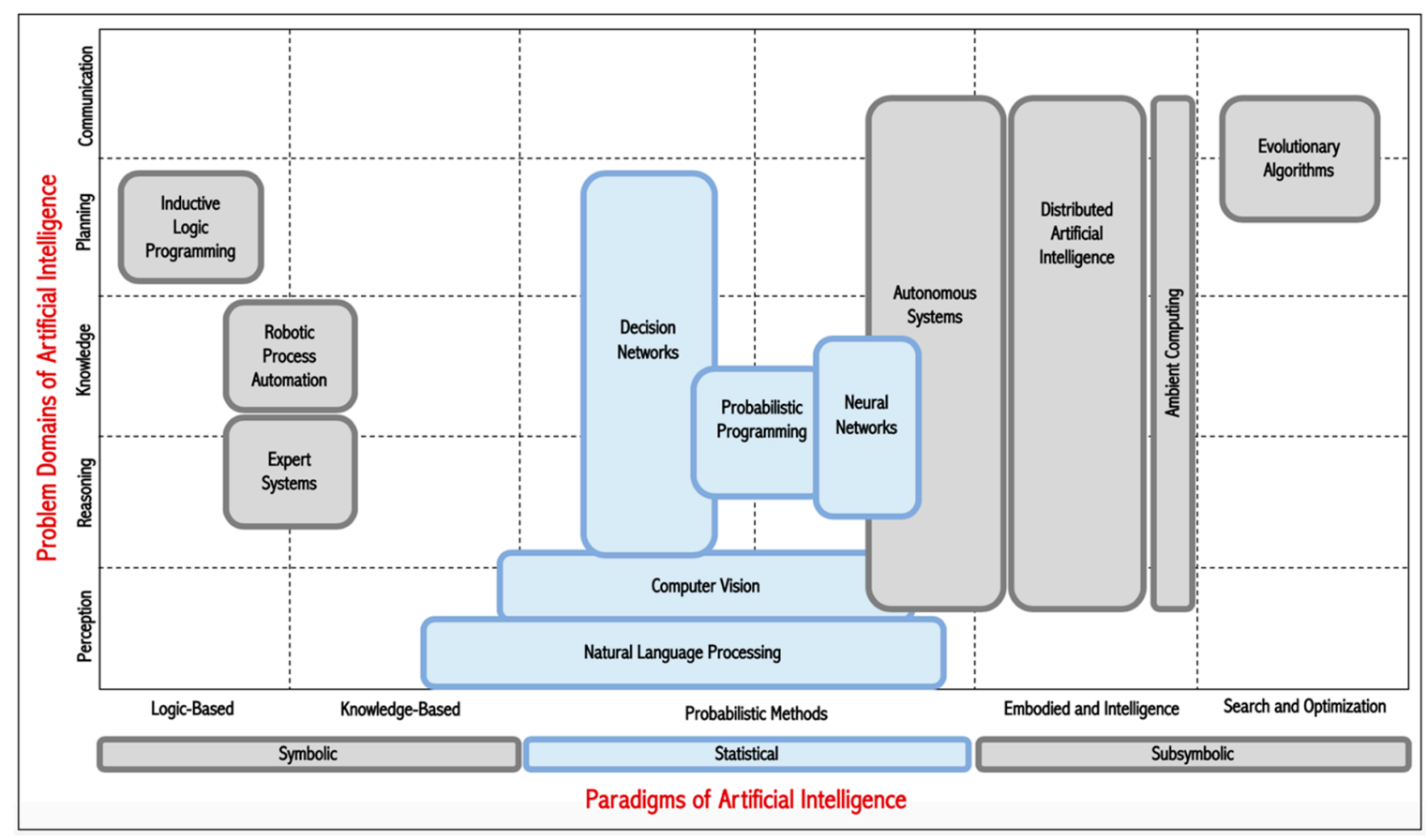

Figure 1. AI knowledge map, derived from [25].

Today, AI applications are being deployed in all facets of cities [26,27]. We can classify these applications based on their underlying AI technologies along with other relevant smart technologies as shown in Figure 1.

AI applications are used to improve and innovate the delivery of public services [28]. Various cities have begun 'robotic process automation' (RPA) projects. These projects are focused on automating tasks that are currently conducted by public workers that are mundane, repetitive, and costly. Thus, freeing up valuable resources to be better deployed. Cities are using RPA to process online applications for items such as permits. RPA follows structured rules to reach an outcome [29].

The interest in autonomous vehicles (AV) is palpable. AVs open opportunities for cities to modernize their public transport infrastructure [30]. Autonomous buses are expected to start carrying fare-paying customers in Scotland by mid-2020 after successful trials across a 14-mile route on the Forth Road Bridge between Fife and Edinburgh. All Nippon Airways (ANA) has commenced trials of autonomous buses with minimal human oversight at Haneda International Airport [31]. Depending on the success of these trials, ANA plans do a full-scale deployment by the end of 2020. In recent times, we have also seen AVs complete successful tests in more complex urban environments including London and Paris [32].

The interest in autonomous systems is not limited to RPA or AVs. Smart cities are exploring how to take advantage of advances in robotics [33]. The City of Houston will be beginning trails of robot police shortly at various transit centers to curb petty crime and free up law enforcement resources [34]. Robots are also being tested to augment law enforcement personnel and lower incidents of conflict between them and the public. In the US where, in recent times, several routine traffic stops have led to confrontations, robots are being tested in mediating encounters between police officers and drivers [35].

Engagement platforms between public agencies and various stakeholders of the city are also being transformed through a range of AI applications. Chatbots are the most popular set of AI applications in this regard. Rammas, a chatbot, was deployed by the Dubai Electricity and Water Authority (DEWA) in January 2017 [36]. DEWA can respond to queries from residents in Arabic and English, and promotes greater knowledge awareness on utility matters. In its first year of operations, Rammas responded to roughly 700,000 queries, which led to an $80 \%$ drop in in-person visits. 
AI systems ingest vast amounts of data, apply learning algorithms, and learn patterns from the data to enable predicting outcomes [37]. Today, cities are deploying machine learning systems to exploit data across their ecosystem from sensors on public infrastructure, to machine readable cards that provide access to city services (e.g., public transport), to images and videos that capture movements around the city, and even devices that capture auditory, olfactory, and tactile data [38,39]. Urban infrastructures, such as traffic lights, are becoming connected. Traffic lights are connected to road sensors to reduce wait time at signals based on the traffic flow. Scotland's Glasgow city has installed networks of sensors that connect to streetlights and traffic lights to help monitor traffic flow and increase connectivity, aggregately reducing travel time for drivers. Further, the traffic data also feeds into maps in real-time to help drivers, cyclists, and pedestrians make decisions to plan their commutes [40].

The Las Vegas Health Department, in partnership with the University of Rochester trialed the nEmesis app which utilized machine learning to collect and examine tweets, the purpose of which was to select restaurants which were suitable for inspection [41]. Following controlled experiments, the nEmesis app was found to be $64 \%$ better at identifying restaurants with food safety issues than established processes involving random inspections. It also had success at identifying restaurants that were unlicensed and had infectious staff. Overall, the app was very effective at helping the Las Vegas Health Department address issues with their restaurant inspection process without the need for additional resources [41]. The harm assessment risk tool (HART) was developed by UK's Durham Constabulary to detect patterns of recidivism among criminals [42]. The tool was trained on crime data from 2008-2012, including information about suspects' gender and zip code. The tool was used to predict the recidivism rate in 2013. It successfully predicted $98 \%$ of low-risk offenders and $88 \%$ of high-risk offenders.

In 2017, the Seattle Police Department launched a data analytics platform to transition towards improved oversight, data-driven decisions, and community engagement [43]. This platform helps the department to manage, govern, and support insightful policing. The system is designed to help the department's leadership team to track trends related to operations. It integrates 17 internally tracked metrics and develops visualizations for department heads. The system tracks several measures such as use-of-force incidents, number of arrests, self-initiated trips, response to calls, number of stops, and civilian complaints. The department can use this detailed information on each police officer to take appropriate measures (e.g., counselling). Since 2012, the police department in San Diego has collected over 65,000 face scans, in an attempt to match them to a directory of over 1 million images collected as part of the San Diego County Sheriff's Tactical Identification System (TACIDS) [44]. More recently, London Metropolitan Police has announced plans to use facial recognition technology to aid police in identifying suspects.

While the housing and urban development space today is data rich, much of the data is often left unanalyzed, thereby resulting in an inability to keep policies and enforcement standards current. Researchers from Georgia Institute of Technology, Emory University, and University of California, Irvine collaborated with the Atlanta Fire Rescue Department (AFRD) to develop an algorithm which was able to predict fire risk in buildings [45]. Using data from 2010-2014, the algorithm included over 50 variables-including property location, building size, structure, age, and history of fire incidents-to predict fire risk. The algorithm classified fire risk ratings for 5000 buildings and found another 19,397 buildings requiring inspection. Furthermore, the algorithm was able to predict $73 \%$ of fire incidents which occurred within the study area [45].

AI-enabled computational tools also help in protecting cyber-infrastructure that is the core fabric of smart cities [46]. Four US cities, namely Pensacola, New Orleans, Galt, and St Lucie, were all victims of different cyberattacks throughout December that rendered telephone and email systems, law enforcement systems, waste, energy, and payment systems inoperable. Often, these attacks demand a ransom, and councils find themselves either paying the attackers or employing external cybersecurity and consulting firms to mitigate and repair the situation. In Lake City, Florida, council 
reluctantly paid a $\$ 460,000$ 'ransom' to attackers after all their council systems were shut down [47]. Researchers from MIT developed an AI platform called AI2 that outperforms existing systems in predicting cyber-attacks [48]. AI2 detects $85 \%$ of cyberattacks, performing about $300 \%$ better than previous systems. The system is also able to reduce the instance of false-positive readings to one-fifth of previous outcomes. This high detection rate is enabled through supervised and unsupervised machine learning.

While we have treated each AI application in isolation, it is common to have them bundled and integrated. Researchers from Carnegie Mellon University collaborated with the City of Pittsburgh to develop a Scalable Urban Traffic Control (SURTRAC), which was able to simultaneously monitor and control the flow of traffic [49]. The system has been deployed in the East Liberty neighborhood since 2012 and covers nine intersections. On average, 29,940 vehicles pass through this area daily. SURTRAC is a schedule-driven system designed to manage multiple competing traffic flows shifts. SUTRAC is a multi-agent decentralized system, where an agent system runs each intersection. Each agent system controls traffic signals for their intersection and monitors traffic flow by dynamically coordinating with other agents in real-time. The deployment of SURTRAC resulted in a 34\% increase in vehicle speed, and a reduction of $25 \%$ in travel time, $40 \%$ in waiting time, $31 \%$ in traffic stops, and $21 \%$ in emissions.

While AI systems have significant potential, their deployments are never straightforward. In Detroit, a \$9 million initiative 'Neighborhood Real-Time Intelligence Program' implemented facial recognition software and video surveillance cameras at 500 different Detroit intersections. This initiative built on the previous 'Project Green Light' Initiative, which installed 500 cameras outside of businesses capable of recording and reporting real time video footage to the police. The software boasts an ability to match faces with 50 million driver's license photographs in the Michigan police database. Nevertheless, recent research has shown that current facial recognition software more often misidentifies black faces than white faces [50]. Whilst intended to increase public safety, there is widespread public criticism directed towards this technology, as residents feel their privacy is compromised and knowledge of the racial biases continues to increase.

Fake news in its purest form refers to completely made up information, nonetheless, such information is often hard to identify as it can resemble credible journalism and attract maximum attention, spreading like wildfire through various social media channels [51]. A man was caught after he carried an assault rifle and fired shots at a pizza parlor in Northwest Washington Upon arrest, the man informed the police that he was investigating a conspiracy theory which claimed that the pizza parlor-Comet Ping Pong — was the headquarters of a pedophilia ring [52]. This incident caused panic among people in the neighborhood, resulting in the lockdown of several businesses.

In Arizona, the hotbed for testing of AVs by major technology providers, we have seen incidents of residents throwing rocks at these vehicles [53]. There, AVs are seen as a threat to jobs, livelihood, and are a source of frustration. As noted by Selby \& Desouza [54], "If theory and practice advance over the next few years without paying attention to fragility, then cities will continue to be vulnerable to manageable threats. As the trends of urbanization continue, it is even more imperative to attend to fractures of social compacts. Cities will continue to grow, and their complexity will only increase. This complexity will continue to mask fragility in the city and could result in the breakdown in one of our society's most valuable artifacts, developed cities, representing a potential loss of life and economic prosperity". AI technologies, for all their good, do make cities more fragile [55] as they put pressures on local governments to maintain existing, and strengthen, social compacts in the face of job losses, automation, shifts in public finances, and so on.

In May 2016, a Tesla Model S car collided with a tractor-trailer in Williston, Florida. The accident occurred on the highway when the car, on autopilot mode, collided with the truck while crossing an uncontrolled intersection. The Tesla driver sustained fatal injuries, raising several questions about the autopilot functionality. However, the National Highway Traffic Safety Administration's (NHTSA) final investigation report concluded that the accident was caused by the driver's inattention [56]. Since 
the accident, Tesla has implemented several features to keep drivers engaged while their car is in autopilot mode.

Chrysler recalled about 1.4 million cars and trucks, because these vehicles could be hacked remotely over the Internet [57]. These vehicles used UConnect features to connect with Sprint networks for navigation. Hackers could access these cars' navigation systems to control air conditioners, cut off brakes, and shut down engines, and so on. Software installed in vehicles need to be constantly upgraded to protect against hacks and security breaches [58].

Economically, local governments may lose revenue streams because of AVs due to a decrease in speeding tickets, towing fees, and driving under influence charges [59]. Cities in Arizona such as Phoenix and Mesa collected about $\$ 10.8$ million and $\$ 4.2$ million from drivers for traffic violations [60]. On an average, cities in California generated $\$ 40$ million in towing violations annually [15].

The conceptual and application background of $\mathrm{AI}$ as presented above underlines the importance of further investigations into how we can best integrate AI systems in addressing critical urban issues. Particularly the challenges we face-e.g., climate emergency-calls for smarter systems in place. This is also highly critical to increase the smartness of our cities. A recent study that evaluated the smartness levels of 180 Australian local government areas argues for the importance of better integration of urban technologies, including AI, into local service delivery and governance [14].

\section{Materials and Method}

We undertook a systematic review of the literature to answer the following research question: How can AI contribute to the development of smarter cities? We adopted a three-phase methodologic approach (Figure 2) following the study steps of Yigitcanlar et al. [61].

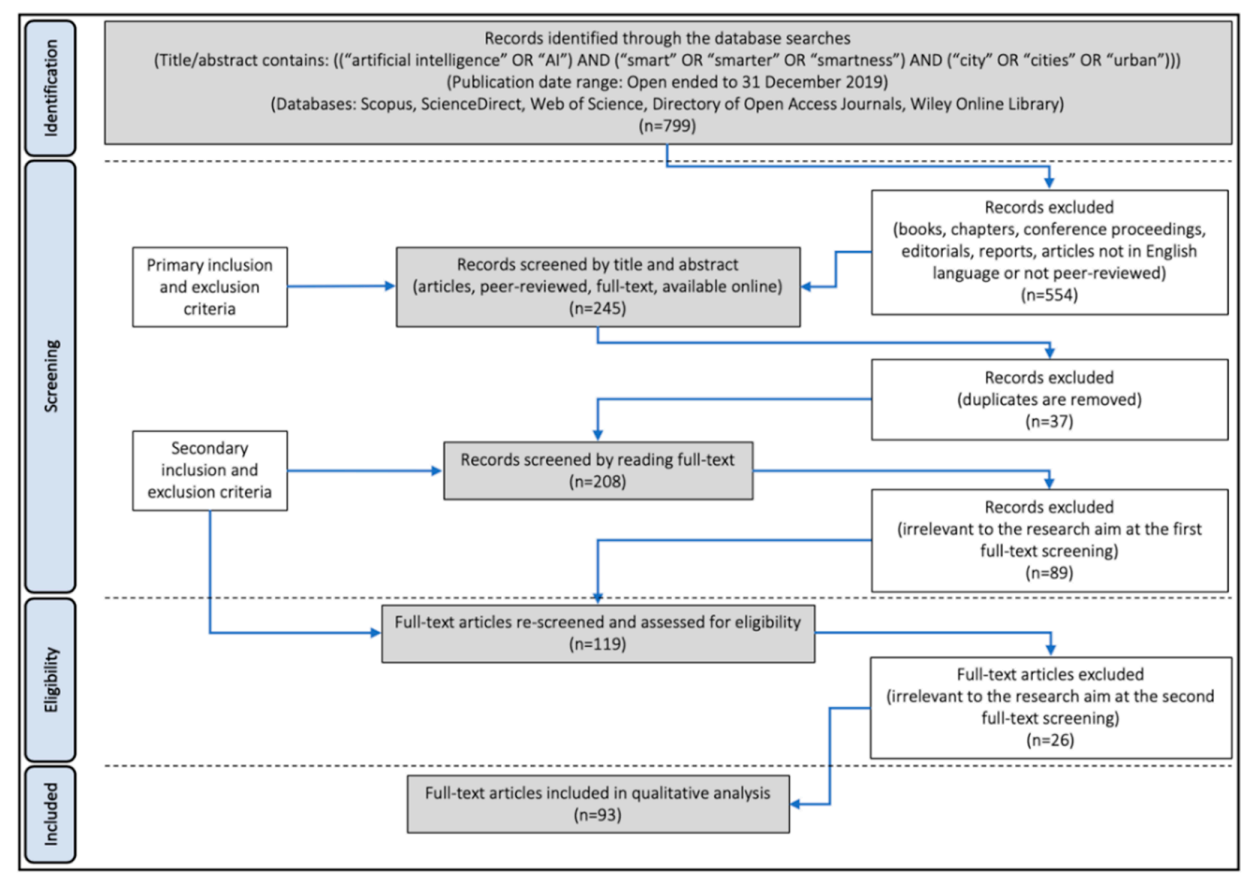

Figure 2. Literature selection procedure.

The first phase is planning, which involves developing the research aim, research question, a list of keywords, and criteria for the inclusion and exclusion of articles. The research aim was framed to generate insights into forming a greater understanding on how AI can contribute to the development of smarter cities. The inclusion criteria were intended to be peer-reviewed journal articles, that were available online, in English, and had relevance with respect to the research aim. A university's library search engine, which gives access to 393 different databases including: Directory of Open Access 
Journals, Science Direct, Scopus, TRID, Web of Science, and Wiley Online Library, was used to complete an online search. The search was carried out towards the end of December 2019 using the query string of (("artificial intelligence" OR "AI") AND ("smart" OR "smarter" OR "smartness") AND ("city" OR "cities" OR "urban")) to search the titles and abstracts of available articles. The publication date was left open. From this search it was determined that the one of the earliest studies on AI and the city was from Schalkoff [23]. The abstracts were then read, and if the article was considered to be relevant to the research aim, the full-text was reviewed to decide whether it was suitable to include in final analysis.

The second phase involved carrying out the review of relevant articles. The initial search resulted in a total of 799 records. These records were then screened and reduced to 245 by applying the inclusion criteria-i.e. journal articles that were peer-reviewed, and available online. The articles were then 'eye-balled' to ensure they were consistent with the keyword search, the abstracts assessed against the research aim, and duplicates removed. The total number of articles was reduced to 208. The full-text of the selected articles were read to determine the relevance with respect to the aim of the study and the results were narrowed down to 119 articles. After another round of full-text screening, the number of articles was reduced to 93 . Finally, these 93 articles were reviewed, categorized, and analyzed. The criteria for formation of the themes is presented in Table 1. For the categorization, the main smart city development dimensions-i.e., economy, society, environment, and governance-were selected. Figure 3 below presents these dimensions in the context of smart cities.

Table 1. Selection criteria for formulating categories.

\begin{tabular}{|c|c|}
\hline \multicolumn{2}{|r|}{ Selection Criteria } \\
\hline 1. & Determine the literature relevant to the research aim by using the eye-balling technique; \\
\hline 2. & Identify the suitable literature pieces focusing on AI and smart cities after reading the full-text; \\
\hline 3. & $\begin{array}{l}\text { Group the identified AI technology, algorithm and application areas with similarities into } \\
\text { broad categories; }\end{array}$ \\
\hline 4. & Narrow down the selected categories and review the reliability of these against other published literature; \\
\hline 5. & Review the selected literature again and update the shortlisted categories if necessary; \\
\hline 6. & Confirm and finalize the categories selected for the classification of literature; \\
\hline 7. & Catalog the literature selected for the review under the selected categories. \\
\hline
\end{tabular}

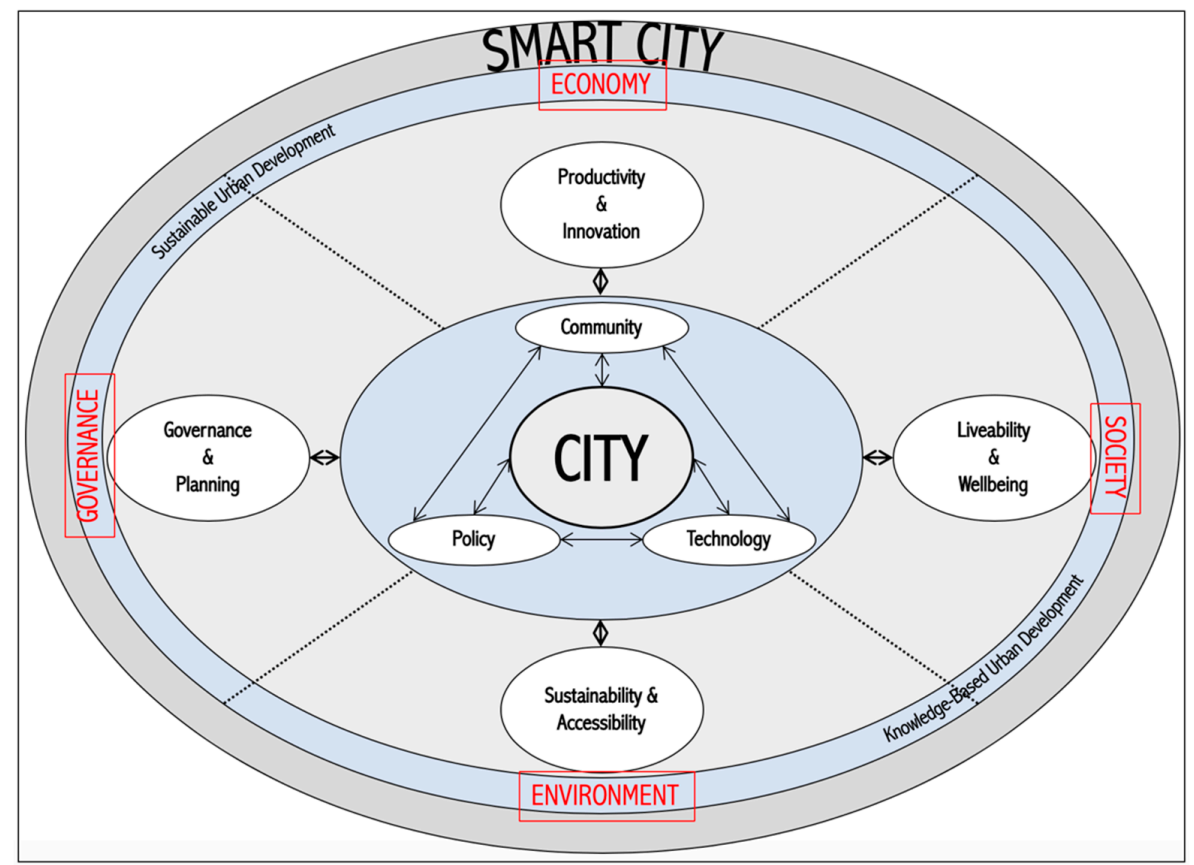

Figure 3. Smart city conceptual framework highlighting key domains, derived from [62]. 
The third and final phase is reporting and dissemination. This phase involved critically documenting and presenting the results from the 93 articles analyzed. A discussion of the perceived benefits and concerns associated with AI implementation were outlined.

\section{Results}

\subsection{General Observations}

The first step in the analysis of the selected 93 articles was to classify them by date of publication. This process revealed interest in AI technology had grown exponentially in recent times. Almost half of the reviewed articles were published in 2019 ( $n=46 ; 49 \%)$, one-fifth in $2018(n=18 ; 20 \%)$, and nearly one-tenth in $2017(\mathrm{n}=8 ; 9 \%)$. Slightly less than a quarter of all articles were published before 2016 $(n=21 ; 23 \%)$. The earliest article included in the literature review was published in 1999. Despite the fact that articles on $\mathrm{AI}$ and the city dated back to 1990, the earliest one that met our selection criteria was [63]. These figures reflect the results of other review studies and are representative of the increased interest in how AI systems interact and impact the development of smart cities [64].

Leading authors are affiliated with institutions in Europe $(n=28)$, East Asia $(n=24)$ and North America $(n=21)$. Nonetheless, the Oceania context, particularly in Australia, is often referenced among the best applications of AI in practice $[65,66]$. Regarding the academic journals, the articles published in IEEE Access appear most often $(n=8)$, followed by Sensors $(n=5)$, and then three articles in both Artificial Intelligence in Medicine $(n=3)$ and Procedia Computer Science $(n=3)$.

Articles were categorized under four groups. These groups were based on the main smart city domains of: (a) Economy; (b) Society; (c) Environment; (d) Government. More than one-sixth of them $(n=17)$ were in the economy domain, slightly more than a quarter $(n=24)$ in the society domain, over one-third $(n=33)$ in the environment domain, and slightly less than quarter of them $(n=19)$ were in the governance domain.

With reference to the 'AI Knowledge Map' (Figure 1), the majority of articles discusses AI applications or techniques that fit within the machine learning paradigm $(n=71)$, followed by probabilistic methods $(n=25)$, knowledge-based $(n=21)$, search and optimization $(n=21)$, logic-based $(n=18)$, and embodied intelligence $(n=15)$. Regarding AI applications, the most commonly mentioned in the selected literature are neural networks $(n=55)$, evolutionary algorithms $(n=21)$, distributed artificial intelligence $(n=15)$, computer vision $(n=13)$, and decision networks $(n=9)$. The most common AI paradigms and applications identified in the literature are outlined in Table 2. A complete list of all articles and the identified AI paradigms, applications, techniques, and supporting technology are shown in Appendix A. Please note, there is some crossover with the number of AI paradigms and applications identified in the literature as many articles discuss multiple, or hybrid AI systems.

We acknowledge that there is a potential risk in bias resulting from our strategy for selecting literature to be included in the review. Our review focused on journals only, whereas cutting edge works in engineering, design, and technology field are often published in conference papers. Nonetheless, in order to complement the reviewed 93 journal articles, the paper also cited or quoted 112 relevant literature pieces on the 'AI and smart cities' topic.

\subsection{AI in the Economy Dimension of Smart Cities}

Papers categorized under the economy dimensions of smart cities are those that provide insights into 'how AI can contribute to and enhance the productivity and innovation of smart cities' [33]. Research in this area focused predominately on technological innovation, economy and management areas, and the contribution of AI can be summarized as: (a) Enhancing productivity and innovation by automating data management and analysis; (b) Reducing costs and increasing resources through pattern recognition; (c) Supporting decision-making by analyzing large volumes of data from multiple sources, and; (d) Drawing conclusions based on logic, reason and intuition. Appendix A lists the analysis highlights of the reviewed literature. 
Table 2. The common AI paradigms and applications identified in the literature.

\begin{tabular}{lll}
\hline Category & Element & Reference \\
\hline AI paradigms & Machine learning & [26]; [63]; [67-70]; [71-135] \\
& Probabilistic methods & [70]; [73-75]; [77]; [80-82]; [87]; [90]; [93,94]; [96-101]; [112-114]; [134]; [136-138] \\
& Knowledge-based & [26]; [63]; [67-71]; [73]; [77,78]; [82]; [92]; [98]; [100]; [112]; [136]; [139-143] \\
& Search and optimization & [26]; [67-69]; [77]; [79,80]; [82]; [86]; [92]; [98]; [101]; [106]; [112]; [116]; [128]; [130]; [134]; [144-146] \\
& Logic-based & [63]; [67,68]; [69]; [71]; [73]; [77,78]; [82]; [92]; [98]; [100]; [112]; [136]; [140-143] \\
& Embodied intelligence & [26]; [70]; [73]; [75,76]; [80]; [82]; [98]; [104]; [116]; [128]; [134]; [137]; [147] \\
\hline AI applications & Neural networks & [26]; [63]; [67-70]; [71]; [73]; [75]; [77-85]; [87]; [89,90]; [92]; [95]; [97-103]; [105-107]; [109-112]; [116-126]; [128-134] \\
& Evolutionary algorithms & [26]; [67-69]; [77]; [79, [80]; [82]; [86]; [92]; [98]; [101]; [106]; [112]; [116]; [128]; [130]; [134]; [144-146] \\
& Expert systems & [26]; [63]; [67-70]; [71]; [73]; [77,78]; [82]; [92]; [98]; [100]; [112]; [136]; [140-143] \\
& Distributed artificial intelligence & [26]; [70]; [73]; [75,76]; [80]; [82]; [92]; [98]; [116]; [128]; [134]; [137]; [147,148] \\
& Computer vision & [73-75]; [87]; [93,94]; [96]; [99]; [101]; [113,114]; [118]; [138] \\
& Decision networks & [70]; [77]; [80]; [82]; [90]; [98]; [112]; [134]; [136] \\
\hline
\end{tabular}


$\mathrm{AI}$ is a useful tool to quickly and accurately manage and analyze large volumes of data to support business decisions [103,112]. This is particularly relevant in combination with IoT-a system enabled by the internet, which allows communication between a large network of devices without the need for human intervention $[77,106,110]$. Together with technologies such as blockchain, cloud storage, and fog computing-which help facilitate the recording, distribution, storage, and decentralized processing of data $[128,149]$ - AI could improve productivity by automating the data management process and removing the need for intermediaries, and hence increasing profitability [126]. Furthermore, AI can improve the stability and effectiveness of IoT contributing to improved network communication. In return, this would help to improve knowledge sharing, and foster innovation and entrepreneurship [106,127,128].

AI can be used to recognize patterns in datasets, helping to optimize the data management process, improve the overall productivity of the data management system [111,149], and identify cyber-attacks [107], coding errors, and other inefficiencies [103]. Deep learning has already had success recognizing patterns from a wide range of data sources including images, audio, video, and other sensors [104]. The application of AI has the potential to remove the need for humans to complete many repetitive business tasks-particularly those relying on observation-, potentially reducing costs and freeing up resources for more productive or innovative fields [112,130].

In analyzing the large amounts of data collected by the sensors, devices, and other sources in a smart city, AI has the potential to accelerate the decision-making process by automating complex statistical analyses $[111,130,150]$. This is particularly relevant with regards to the application of deep learning technology to the process of data fusion-i.e. the processes of taking data from a variety of sources, combining it, and improving its quality and usefulness by producing sophisticated statistical models [126]. AI has the capability to automate this process and conduct statistical analyses that are much larger and more complex than could be completed with human intervention. This information can then be used to reduce economic uncertainty and assist business decisions $[77,103,107]$, and/or create marketplaces that are more responsive to user needs and desires [130].

The ability of AI to complete complex statistical analysis can also be used to automate decision-making $[128,130,150]$. The ability to learn, can ensure that AI systems are responsive to uncertainty, particularly when working with and around humans $[94,119]$. This can reduce the possibilities of accidents, errors, and improve the operational efficiency of business and industries [119]. Smart control systems can monitor traffic, collect and analyze data and in combination with connected-AVs there is potential to make real-time decisions which enhance the efficiency of transport operations-including freight and supply chain logistics [104,130]. AI systems can be developed with human-like abilities, such as creativity, design, intuition, inventiveness, trust, ethics, and values to perceive, understand, and make informed, reason-based decisions that would benefit companies [76,94].

\subsection{AI in the Society Dimension of Smart Cities}

Papers in this category provide insights into 'how AI can contribute to and improve the livability and wellbeing of citizens in smart cities' [33]. Research in this area focused predominately on the health and education sectors, and the contributions of AI can be summarized as: (a) Improving health monitoring; (b) Enhancing health diagnosis outcomes, and; (c) Providing autonomous tutoring systems that are highly individualized and adaptive to needs and external changes. Appendix A lists the analysis highlights of the reviewed literature.

AI systems, in combination with sensors, cameras and other data collection devices, have been developed to monitor the health and wellbeing of individuals $[70,87]$. Machine learning techniques can be used to improve the cost and efficiency of fall detection devices [99], and detect changes in sleep, mood, heartbeat, respiration, and other vital signs [118,129]. Wearable devices, or 'smart textiles, enabled by AI, can detect changes in the human body and report findings to health care providers [129]. In intensive care settings, monitoring devices equipped with AI can be used to adjust the settings on bedside devices reducing total healthcare costs and improving patient outcomes [67]. In rural 
settings, the ability to monitor patients remotely could contribute to reduced inequities and improve access to healthcare [89]. This is a particularly critical issue in countries like Australia, where in some remote areas the nearest health service provider or hospital could be located 1,000 km or further [151]. Additionally, the smart tracking of health symptoms could improve communication between patients and health care professionals [142].

In addition to health monitoring, AI systems can greatly improve health diagnosis by providing an effective repository of medical knowledge and the ability to access, analyze, and apply complex medical data more efficiently $[68,139]$. Assisting health care workers with tasks involving the collection and recording of data and knowledge could increase the amount of resources available for patient care $[68,139]$, improve the quality of life for patients [120], and expand the professional learning capabilities of professionals [122]. Similarly, the improved analytics and reasoning capabilities of AI would provide a decision-support mechanism with the potential to reduce chances of misdiagnosis [137], facilitate greater communication and collaboration between health care professionals [70], and assist with the development of more personalized medical treatments [91,137].

With regards to the education sector, intelligent tutoring systems that mimic the one-on-one interaction between tutor and student can provide highly individualized teaching programs for students [140]. Furthermore, these systems can develop multiple paths to answer any given question and provide highly detailed feedback [140]. Advances in AI technology can increase the effectiveness of these, and similar systems by automatically collecting information from the web, ensuring the most up-to-date content, and using machine learning to increase the adaptability to individualized learner requirements $[81,146]$. There is potential to create systems that are far more effective than one-on-one tutoring [143], with improved communication between student and teacher, and superior assessment methods [85]. This is especially promising with regards to identifying and adapting syllabus to the individual strengths and needs of students with learning disabilities or other special learning requirements [71].

Increased adaptability is important as rapid technological changes are likely to result in an unstable job market $[135,143]$. AI could potentially bring new skill requirements across multiple sectors and the education sector needs to be at the cutting edge of these changes to ensure students are prepared for future job markets [152]. For example, even in the education sector itself, AI will replace many of the time-consuming tasks, changing teacher roles to one based on student support and the management of AI systems $[88,135,153]$. Managing the education needs of residents is therefore important to ensure they are able to take advantages of the potential benefits of AI including improved working conditions, better work-life balance, and improved quality of life [135].

Lastly, AI has been used for the modelling of the spread of the recent COVID-19 epidemic. The predictions seem to be showing reliable results as the modelling predicts COVID-19 infections with an accuracy of $96 \%$, and deaths with an accuracy of $99 \%$, up to one week into the future. This information would help governments implement effective contingency plans, and prevent the virus's spread and turn into a global pandemic [154]. Similarly, Lin et al. [155] utilize blockchain with AI to efficiently manage water use under the changing climate conditions, and contribute to climate change adaptation efforts.

\subsection{AI in the Environment Dimension of Smart Cities}

These papers provide insights into 'how AI could contribute to sustainable urban development and improved accessibility in smart cities' [33]. Research in this area focused predominately on the transport, energy, land use, and environment sectors/areas, and the contribution of AI can be summarized as: (a) Monitoring changes in the environment; (b) Using smart energy systems to optimize energy consumption and production; (c) Planning, development, and use of households to reduce energy consumption, and; (d) Operationalizing smart transport systems. Appendix A lists the analysis highlights of the reviewed literature. 
When faced with complex environmental issues and large quantities of data, AI systems have the potential to make knowledge-based decisions that balance the environmental outcomes of the city against the social and economic wellbeing of its residents $[63,136]$. AI systems can be used to monitor changes in the environment including, noise, temperature, humidity, emissions [90], water pollutants [133], fish stock, and other environmental indicators [136]. AI systems can respond to these changes, and quickly implement solutions for dealing with any issues [156]. Furthermore, improved data quality from AI systems can contribute to more robust and accurate environmental modelling systems [69,124].

AI has also been identified as a means of creating more energy efficient cities [156]. Smart grid systems, integrated with AI technology, can be used to control power systems and optimize energy consumption [78,79]. Including the planning and management of electric vehicle charging [145], public lighting [75], and data [121]. AI can also assist with the distribution of renewable electricity generated from multiple, often non-traditional sources—including body heat [125]—, the identification of inefficiencies, and future forecasting [134,157]. By optimizing the management of resources, monitoring energy consumption, and better planning for future requirements, cities will be able to use resources more efficiently and better achieve renewable energy goals $[80,86]$.

Smarter homes can be developed with AI systems that monitor changes in the environment, adapt to user requirements, and improve energy efficiency $[73,92,116]$. AI systems could be used to predict future household energy requirements which can help identify inefficiencies, faults, and control future energy use [81]. In addition, AI can contribute to reduced energy consumption in the construction process [102], and improved environmental outcomes in the design [146] and planning process [26].

With regards to sustainable transportation, the goal of AI in the context of smart cities is to calculate the most efficient means of moving people and goods between places, reducing the number of vehicle kilometers traveled (VKT). This in turn leads to a reduction in energy consumption which in turn leads to lower air and noise pollution, congestion, and other externalities such as the requirements for transportation and parking infrastructure $[98,156]$. AI can be used for transport optimization by analyzing real-time measurements—such as traffic signal control—to adjust routes [74,97], balance user demands [96], and make parking more efficient [104,113]. Particularly in AVs, these changes can result in substantial reductions in travel time and energy savings [108]. From a transport planning perspective AI can also be used to differentiate spatial structures in aerial images [113] and collect masses of data for the development of more accurate, and responsive models which can be used to develop a more environmentally efficient transportation system [117].

Despite no studies in the reviewed literature directly focus on how AI can tackle climate change, we are aware of some relevant research. For instance, in their paper entitled 'tackling climate change with machine learning', Rolnick et al. [158] offer areas where machine learning can be deployed. These areas include better climate predictions and modeling, energy production, $\mathrm{CO}_{2}$ removal, education, solar geoengineering, and finance. Within these areas, the possibilities include more energy-efficient buildings, creating new low-carbon materials, better monitoring of deforestation, and greener transportation. They state that "although AI is not a silver bullet, it brings new insights into the problem". Another study, by O'Gorman \& Dwyer [159], demonstrates the use of machine learning to parameterize moist convection and climate change, and extreme event modelling. Likewise, Dayal et al. [160] model Queensland (Australia) droughts based on AI and neural network algorithms for decision-makers and local inhabitants to take precautions.

\subsection{AI in the Governance Dimension of Smart Cities}

How AI can contribute to establishing good governance and planning in smart cities is the focus of this set of papers [33]. Research in this area focused predominately on the security, governance and decision-making areas, and the contributions of AI can be summarized as: (a) Enhancing the operability of surveillance systems; (b) Improving cyber security; (c) Aiding the disaster management planning and operations, and; (d) Assisting citizens with new technology to support citizen scientist 
and contribute to the urban decision-making process. Appendix A lists the analysis highlights of the reviewed literature.

Advanced AI surveillance technologies, enabled by motion detection, predictive analytics, drones, and other autonomous devices, can be used to monitor urban areas, recognize threats, such as crime $[72,93,100,148]$, fraud [109], accidents, and fire [101,123,160]. On a broader scale, AI can be used to monitor communication networks and recognize potential terrorist threats, trafficking, crime syndicates, and other illegal behavior [100]. Once targets are identified, intelligent surveillance systems can evaluate and track targets [93], and collect forensic evidence—such as video recording [138]. AI can also be used to better predict future crime incidents and ensure the optimal allocation of crime law enforcement [144].

Cyber threats also pose significant risks to smart cities both in terms data privacy and the protection of connected infrastructure $[83,161,162]$. AI can be used to identify irregular behavior, determine what is a threat and implement mitigation measures at speeds beyond that of human ability $[83,100]$. This together with encryption technologies such as blockchain [100], and a focus on data security at all levels of design [131], can alleviate individual concerns regarding data security and contribute to increased transparency and trust regarding online systems [83,141]. This would allow increased avenues for citizen engagement in policy decisions and citizen scientist engagement with policy development via crowdsourcing [163], along with other online services such as electronic voting [141] and smart contracts [115].

Given the ability of AI to analyze large amounts of data, scenarios to deal with potential threats could be constructed simultaneous to the detection of threats [161]. This would give decision-makers and other authorities more time to respond to threats such as natural disasters [132], house fires [123], or other incidents. Furthermore, AI can be used to assess the extent of damage caused by these events helping authorities better respond to, and mitigate any damage caused [101,132].

Finally, AI systems can be used to both assist and analyze acceptance of new systems-particularly those associated with new technologies $[109,163]$. Online 'chatbots' can help residents navigate new websites and online platforms [109], with training and tips customized based on individualized needs and interests [164]. Furthermore, AI use reasoning and intuition to assist decision-makers understand the reasons behind citizen acceptance, or non-acceptance, of new technology [165]. Where new approaches are required, AI can develop innovative solutions [95] and address future challenges [84].

\section{Discussion}

This review study investigated the impact of the two very powerful and highly popular phenomena of our time, i.e., AI and smart cities. On the one hand, the smart city notion is seen as a potential blueprint for the development of future cities to provide improved productivity, innovation, livability, wellbeing, sustainability, accessibility, governance, and planning $[166,167]$. Nevertheless, we still do not have the technical capabilities to develop these technologically advanced futuristic cities [168]. On the other hand, AI provides a hope for overcoming the limits of human capabilities, in the computational sense [169]. Hence, in theory, a happy marriage of AI and the smart cities concept would bring us closer to producing smarter cities [22].

In this paper, we attempted to generate insights into forming a better understanding on how AI can contribute to the development of smarter cities by undertaking a systematic review of the literature. Appendix A lists the analysis highlights of the reviewed literature. The results of the review disclosed the following main points, and some of the critical issues are discussed further:

1. AI has an evident potential to provide a positive change in our cities, societies and businesses by promoting a more efficient, effective and sustainable transition/transformation;

2. AI, with its technology, algorithms, and learning capabilities, can be a useful vehicle in automating the problem solving and decision-making processes; that in return could reform urban landscapes, and support the development of smarter cities; 
3. $\mathrm{AI}$ in the context of smart cities is an emerging field of research and practice. Hence, further research is needed to consolidate the knowledge in the field;

4. The central focus of the literature is on AI technologies, algorithms, and their current and prospective applications;

5. AI applications in the context of smart cities mainly concentrate on business efficiency, data analytics, education, energy, environmental sustainability, health, land use, security, transport, and urban management areas, and;

6. Upcoming disruptions of AI on cities and societies have not been adequately investigated in the literature; thus, further investigations are needed on that issue.

The results of the review revealed that AI-inspired computational systems are bound to make a profound impact on our cities. The impact will not only be on the physical setup of our cities but also in how our cities operate and achieve system-level objectives (e.g., livability, resilience, and so on). In order to ensure that cities advance in keeping with the values and aspirations of their key stakeholders (i.e., residents, businesses, and so on), it will be vital for us to ensure that AI systems are designed take on a value-sensitive design approach [170]. AI systems will need to account for the multiple aspects of diversity that are omnipresent in our cities. In addition, these systems will need to possess a degree of transparency, adaptability (to respond to varying environmental conditions), and accountability (for levels of performance). Doing so is non-trivial, but paramount to achieving responsible innovation in the context of $\mathrm{AI}$ and cities.

While advances in computational science and technologies will continue to progress at an astounding rate, the level of impact they will have on our future cities comes down to the level of trust individuals and organizations place in these systems. As we continue to live through times where levels of trust in government are at an all-time low [171], planners and public managers needs to consider how social license [172] impacts their ability to deploy emerging technologies. Engaging stakeholders into the design processes when it comes to AI-systems will be critical. Stakeholders should be allowed to shape the elements of these systems and their expected deployment trajectories. Engaging stakeholders will also enable a city to increase the overall knowledge of the community when it comes to the innovative potential of these technologies. To date, we have limited frameworks on how to engage many diverse stakeholders, who have varying knowledge of the intricacies of AI systems, into design processes for urban innovation [173].

We need to enable multiple stakeholders to contribute their technology solutions. Cities need to build platforms that promote the co-creation and sharing of technology solutions $[174,175]$. While cities have embraced the notion of open data [176] and have created periodic programs to source innovation from external stakeholders (e.g., Hackathons) [177], much more is needed when it comes to designing platforms for co-creation in the context of AI technologies. Stakeholders can be engaged in the auditing of algorithms that underlie AI applications. In addition, they can provide feedback on the performance of these systems, and identify critical choke points. As an example, consider the following innovation by a resident in Berlin, who was able to create traffic jam alerts on Google Maps by slowly moving 99 phones with location services turned on around the city [178]. Residents, such as this individual, enable us to see the limits of AI technologies and their failure points. Such perspectives are critically important as we infuse and design next-generation smart urban technologies.

AI systems will impact cities at multiple levels, from the individual, to the local community (the residents), the neighborhood to the organizational (the city), and even the ecosystem (the city is connected to other cities) level. Impacts at the local level, will have effects up and down the hierarchy. Consider the case of algorithms used to promote sharing economy platforms (e.g., Uber, Lyft, AirBnB, and so on). These algorithms not only provide opportunities to individuals to earn rent on their assets and fees for their services, they also impact zoning rules, they impact the use of established public transport networks, they in turn impact the creation of new service opportunities for existing businesses, and even shape the nature of public finances of a city. More effort is needed to understand the cascading effects of AI innovations across the various levels of a city's functions. In addition, the 
interdependencies between functions and the implications for overall objectives (i.e., ensuring that local optimization does not compromise global performance) is also critical.

From a design perspective, research on how to design AI technologies in a more agile [179] and frugal $[180,181]$ manner is of critical importance. The public sector has a notorious record of accomplishment when it comes to managing, and delivering on, information systems projects [182]. Cities around the world have had to contend with failed deployments of information system projects that has wasted significant public resources. The study by Desouza et al. [183] provides examples of both success and failure factors of technology-driven smart city attempts, including AI.

Given the significance of technology investments in our cities, we need to see vast improvements in projects management to deliver on their intended value. In this regard, two considerations are critical. First, we must build technologies that are agile, i.e., they have the ability to adopt, adjust, and have the capacity for transformation under changing environmental conditions. Second, we must build technologies in a manner that is in keeping with frugal engineering. Doing so will require us to move away from mega-scale smart cities projects and reconsider the issue of scale. Today, a dominant design paradigm is to build AI technologies that can scale and promote the re-use of components. This thinking is outdated. Today, it is possible to build technologies that work for specific contexts, in an agile and frugal manner, to promote personalization to a specific context and purpose [184].

The security of our next-generation urban technologies is of paramount importance. AI technologies, like most technologies, should be secured and this normally takes the form of traditional information security. Technologies that traverse our urban environments are already targets of hackers and have vulnerabilities. For instance, Greenberg [185] highlights a deep flaw in cars that lets hackers shut down safety features. But, even beyond what one thinks of when it comes to traditional security, today, AI-driven systems can cause harm even if they are not hacked. For example, as stressed by the BBC [186], China coronavirus misinformation spreads online about its origin and scale, i.e., AI inspired platforms that are used for different urban functions can also be manipulated to spread fake news. Cities need to be aware of this as they use these platforms to share information on urban functions, such as the use of social media to engage with citizens. For instance, as reported by Martinez [187], "Rumors of child abductors spread through WhatsApp in a small town in Mexico ... . The rumors were fake, but a mob burned two men to death before anyone checked." Likewise, as we have discussed earlier, cities have had their information systems been held for ransom. The incidents will only increase as cities infuse more technologies into their environments. Hence, there is a need for research to examine the security and risk implications of AI-enabled system deployments.

The success of AI deployment to make our cities smarter will depend on the knowledge and care with which such technologies are deployed responsibility and in keeping with our public values. If done well, AI can help us tackle some our most complex urban challenges. However, it can also make our cities more fragile [54]. As stated by Stephen Hawking on the BBC, "The development of full artificial intelligence could spell the end of the human race. It would take off on its own, and re-design itself at an ever-increasing rate. Humans, who are limited by slow biological evolution, couldn't compete, and would be superseded."

On that very point, Gherhes and Obrad [188] report the findings of their study on technical and humanities student perspectives on the development and sustainability of AI. The study discloses that out of 928 participants $58.3 \%$ considers that AI will have a positive influence on the society. On the other hand, the percentage of those confessing to being confused or concerned is also quite significant $(41.7 \%)$. The probability that AI might destroy humankind and replace people in certain activities and jobs are among the greatest fears [188].

As the AI applications are becoming more common, there grows the skepticism on the misuse of the technology. For example, most recently the Clearview AI facial recognition system has generated major concerns on the privacy issues. Australian police have been using this unaccountable facial recognition service that combines machine learning and wide-ranging data gathering practices to identify members of the public from online photographs. As stated by Golenfein [189] "Beyond the 
ethical arguments around facial recognition, Clearview AI reveals Australian law enforcement agencies have such limited technical and organizational accountability that we should be questioning their competency even to evaluate, let alone use, this kind of technology". Similarly, the New South Wales state government of Australia is using AI to spot drivers with mobile phones (often mixed phones with other rectangular items), and the Australian government welfare agency Centrelink is using AI (often incorrectly) to issue debt notices to welfare recipients [190].

Furthermore, scholars warn us of the possible risks of advanced AI. For instance, these risks range from unsafe recommendations for treating illnesses [191] to fatal autonomous car accidents [192], and from racist chatbots [193] to social manipulation [194]. While various dystopian futures have been advanced, including those in which humans eventually become obsolete, with the subsequent extinction of the human race, [195] put forward the following scenarios to think about the ways to protect us from the risks of advanced AI: (a) An AI system tasked with preventing HIV decides to eradicate the problem by killing everybody who carries the disease, or one tasked with curing cancer decides to kill everybody who has any genetic predisposition for it; (b) An autonomous AI military drone decides the only way to guarantee an enemy target is destroyed is to wipe out an entire community, and; (c) An environmentally protective AI decides the only way to slow or reverse climate change is to remove technologies and humans that induce it.

Lastly, abovementioned challenges also relate to the specific characteristics of AI technologies that include opacity ('black box-effect'), complexity, unpredictability and partially autonomous behavior, may make it hard to verify compliance with and may hamper the effective enforcement of rules of existing laws meant to protect fundamental rights [196]. In order to address this issue, the [197] white paper entitled 'Artificial intelligence: a European approach to excellence and trust' underlined the following seven key requirements for a successful AI utilization: (a) Human agency and oversight; (b) Technical robustness and safety; (c) Privacy and data governance; (d) Transparency; (d) Diversity, non-discrimination, and fairness; (e) Societal and environmental well-being, and; (f) Accountability. On that very point, Salmon et al. [195] propose the immediate application of the following three sets of controls for AI development and testing: (a) The controls required to ensure AI system designers and developers create safe AI systems; (b) The controls that need to be built into the AIs themselves, such as 'common sense', morals, operating procedures, decision-rules, and so on, and; (c) The controls that need to be added to the broader systems in which AI will operate, such as regulation, codes of practice, standard operating procedures, monitoring systems, and infrastructure. As Elon Musk stated, "we need to regulate AI to combat an 'existential threat' before it's too late" [198]. Fortunately, we are not short of ideas and plans to tackle these issues, and now is the time to implement them before it is too late [199].

\section{Conclusions}

The study reported in this paper offers a novel contribution to the literature by mapping out the scientific landscape of the understudied 'AI and the smart city' area. This study helps not only in identifying the current and potential contributions of AI to the development of smarter cities-to aid urban policymakers, planners and researchers-, but also in determining the gaps in the literature to bridge them in prospective studies. The study also gives a heads up for urban policymakers, planners and scholars for them to prepare for the disruptions that AI will cause in our cites, societies and businesses [200].

The broad findings of our systematic literature review findings reveal that: (a) AI has an evident potential—but only if utilized responsibly [201] — to provide a positive change in our cities, societies, and businesses by promoting a more efficient, effective and sustainable transition/transformation [202,203], and; (b) Particularly, AI, with its technology, algorithms, and learning capabilities, can be a useful vehicle in automating the problem solving and decision-making processes that, in return, could reform urban landscapes and support the development of smarter cities [62]. 
The specific findings of our systematic literature review disclose that: (a) AI in the context of smart cities is an emerging field of research and practice; (b) The central focus of the literature is on AI technologies, algorithms, and their current and prospective applications; (c) AI applications in the context of smart cities mainly concentrate on business efficiency, data analytics, education, energy, environmental sustainability, health, land use, security, transport, and urban management areas; (d) There is limited scholarly research investigating the risks of wider AI utilization, and; (e) Upcoming disruptions of $\mathrm{AI}$ on cities and societies have not been adequately investigated in the literature.

AI provides a new hope for addressing some of the urbanization problems we failed to solve due to the complexities involved. Nevertheless, AI is not a silver bullet. While we are currently far away from such advance application of AI, there are numerous contributions of the rapidly developing technology for our cities and societies. Some of these contributions are presented in the paper and some warnings have been made for the good use of the technology. While there is a promise of the emerging advanced technologies, such as AI, our rapid urbanization, industrialization, and globalization practices are perhaps making even technology struggle with coming up solution. The recent anthropogenic climate change triggered environmental catastrophes and disasters—such as 2020 Australian Bushfires-and urbanization and globalization triggered epidemics—such as COVID-19-require more than technology for them not to be repeated again.

The paper opened with a viewpoint on technocentric solutions being widely seen as remedies for global issues-including climate change and urbanization problems. Indeed, AI and other technologies will definitely equip us with better data analytics and prediction models in more efficient and effective ways. To date, there are two different approaches to AI: rules-based (coded algorithms of if-then statements that are basically meant to solve simple problems) and learning-based (diagnoses problems by interacting with the problem), where both AI approaches have valid use cases when it comes to studying the environment and solving climate change. In other words, when it comes to helping solve climate change, a learning-based AI could essentially do more than just crunch $\mathrm{CO}_{2}$ emission numbers, where a learning-based AI could actually record those numbers, study causes and solutions, and then recommend the best solution [204] —'in theory'. We say 'in theory', because "fully functioning AI systems do not yet exist, and it has been estimated that they will be with us anywhere between 2029 and the end of the century" [195].

While we do not disagree with the positive contributions of technological prescriptions-such as $\mathrm{AI}$ and other urban technologies-[205], we close the paper with the following quote by Andrew $\mathrm{Ng}$, co-founder and lead of Google Brain. "Much has been written about AI's potential to reflect both the best and the worst of humanity. For example, we have seen AI providing conversation and comfort to the lonely; we have also seen AI engaging in racial discrimination. Yet the biggest harm that AI is likely to do to individuals in the short term is job displacement, as the amount of work we can automate with $\mathrm{AI}$ is vastly bigger than before. As leaders, it is incumbent on all of us to make sure we are building a world in which every individual has an opportunity to thrive."

Author Contributions: T.Y. designed the study, supervised the systematic review, and prepared the first draft of the manuscript. L.B. and F.R. undertook the systematic review tasks, and identified the key findings. K.C.D. contributed to the write up and improved the rigor, relevance and reach of the study. All authors have read and agreed to the published version of the manuscript.

Funding: This research received no external funding.

Acknowledgments: This research did not receive any specific grant from funding agencies in the public, commercial or not-for-profit sectors. The authors thank the managing editor and anonymous referees for their invaluable comments on an earlier version of the manuscript.

Conflicts of Interest: The authors declare no conflict of interest. 


\section{Appendix A}

Table A1. Analysis Highlights of the Reviewed Literature.

\begin{tabular}{|c|c|c|c|c|c|c|c|c|c|}
\hline Author & Title & Journal & Aim & Relevance & Domain & Paradigm & Application & Method & Technology \\
\hline $\begin{array}{l}\text { Abduljabbar et al. } \\
\text { [98] }\end{array}$ & $\begin{array}{l}\text { Applications of artificial } \\
\text { intelligence in transport }\end{array}$ & Sustainability & $\begin{array}{l}\text { To provide an overview } \\
\text { of AI techniques } \\
\text { applied to transport. }\end{array}$ & $\begin{array}{l}\text { Advocates that AI in the } \\
\text { transport field is aimed at } \\
\text { decreasing VKT thus } \\
\text { reducing emissions and } \\
\text { other environmental } \\
\text { degradation. }\end{array}$ & Environment & $\begin{array}{l}\text { LB } \\
\text { KB } \\
\text { PM } \\
\text { ML } \\
\text { EI } \\
\text { SO }\end{array}$ & $\begin{array}{l}\text { ES } \\
\text { DN } \\
\text { NN } \\
\text { DAI } \\
\text { EA }\end{array}$ & $\begin{array}{l}\text { FS } \\
\text { DL } \\
\text { SI } \\
\text { GA }\end{array}$ & $\begin{array}{l}\text { Smart } \\
\text { Transport }\end{array}$ \\
\hline Ajerla et al. [99] & $\begin{array}{l}\text { A real-time patient } \\
\text { monitoring framework for } \\
\text { fall detection }\end{array}$ & $\begin{array}{l}\text { Wireless } \\
\text { Communications } \\
\text { and Mobile } \\
\text { Computing }\end{array}$ & $\begin{array}{l}\text { To develop a framework } \\
\text { that uses edge } \\
\text { computing to send data } \\
\text { from wearable devices. }\end{array}$ & $\begin{array}{l}\text { Describes the use of } \\
\text { machine learning in } \\
\text { improving fall detection } \\
\text { devices. }\end{array}$ & Society & $\begin{array}{l}\text { PM } \\
\text { ML }\end{array}$ & $\begin{array}{l}\mathrm{NN} \\
\mathrm{CV}\end{array}$ & $\mathrm{AR}$ & $\begin{array}{l}\text { IoT } \\
\text { Smart Health }\end{array}$ \\
\hline Alam et al. [77] & $\begin{array}{l}\text { Data fusion and IoT for } \\
\text { smart ubiquitous } \\
\text { environments }\end{array}$ & IEEE Access & $\begin{array}{l}\text { To review existing } \\
\text { literature on data fusion } \\
\text { and IoT with a focus on } \\
\text { mathematical models. }\end{array}$ & $\begin{array}{l}\text { Discusses the benefits of } \\
\text { AI in relation to data } \\
\text { fusion. }\end{array}$ & Economy & $\begin{array}{l}\text { LB } \\
\text { KB } \\
\text { PM } \\
\text { ML } \\
\text { SO }\end{array}$ & $\begin{array}{l}\text { ES } \\
\text { DN } \\
\text { NN } \\
\text { EA }\end{array}$ & $\begin{array}{l}\text { FS } \\
\text { BN } \\
\text { DL } \\
\text { GA }\end{array}$ & IoT \\
\hline $\begin{array}{l}\text { Allama \& } \\
\text { Dhunny [100] }\end{array}$ & $\begin{array}{l}\text { On big data, artificial } \\
\text { intelligence and smart cities }\end{array}$ & Cities & $\begin{array}{l}\text { To provide information } \\
\text { on the use of AI and big } \\
\text { data in smart cities. }\end{array}$ & $\begin{array}{l}\text { Provides insights } \\
\text { regarding the application } \\
\text { of AI to public safety and } \\
\text { security. }\end{array}$ & Governance & $\begin{array}{l}\text { LB } \\
\text { KB } \\
\text { PM } \\
\text { ML }\end{array}$ & $\begin{array}{l}\text { ES } \\
\text { NN }\end{array}$ & FS & IoT \\
\hline $\begin{array}{l}\text { Alsamhi et al. } \\
\text { [101] }\end{array}$ & $\begin{array}{l}\text { Survey on collaborative } \\
\text { smart drones and internet } \\
\text { of things for improving } \\
\text { smartness of smart cities }\end{array}$ & IEEE Access & $\begin{array}{l}\text { To show how drones } \\
\text { and IoT can improve the } \\
\text { smartness of cities. }\end{array}$ & $\begin{array}{l}\text { Provides insights into } \\
\text { how autonomous drones } \\
\text { can be used for security, } \\
\text { safety measures. }\end{array}$ & Governance & $\begin{array}{l}\text { PM } \\
\text { ML } \\
\text { SO }\end{array}$ & $\begin{array}{l}\mathrm{NN} \\
\mathrm{CV} \\
\mathrm{EA}\end{array}$ & $\begin{array}{l}\text { AR } \\
\text { IR } \\
\text { MV } \\
\text { GA }\end{array}$ & $\begin{array}{l}\text { IoT } \\
\text { Drones }\end{array}$ \\
\hline $\begin{array}{l}\text { Altulyan et al. } \\
\text { [149] }\end{array}$ & $\begin{array}{l}\text { A unified framework for } \\
\text { data integrity protection in } \\
\text { people-centric smart cities }\end{array}$ & $\begin{array}{l}\text { Multimedia Tools } \\
\text { and Applications }\end{array}$ & $\begin{array}{l}\text { To address data } \\
\text { integrity from an } \\
\text { end-to-end perspective. }\end{array}$ & $\begin{array}{l}\text { Describes how block } \\
\text { chain and fog computing } \\
\text { can be used to manage } \\
\text { data integrity. }\end{array}$ & Economy & $\mathrm{n} / \mathrm{a}$ & $\mathrm{n} / \mathrm{a}$ & $\mathrm{n} / \mathrm{a}$ & IoT \\
\hline $\begin{array}{l}\text { Alzoubi et al. } \\
\text { [102] }\end{array}$ & $\begin{array}{l}\text { Prediction of environmental } \\
\text { indicators in land levelling } \\
\text { using artificial intelligence } \\
\text { techniques }\end{array}$ & $\begin{array}{l}\text { Journal of } \\
\text { Environmental } \\
\text { Health Science and } \\
\text { Engineering }\end{array}$ & $\begin{array}{l}\text { To develop AI } \\
\text { techniques in land } \\
\text { levelling. }\end{array}$ & $\begin{array}{l}\text { Discusses using AI in } \\
\text { land levelling. }\end{array}$ & Environment & ML & $\mathrm{NN}$ & $\mathrm{n} / \mathrm{a}$ & $\mathrm{n} / \mathrm{a}$ \\
\hline $\begin{array}{l}\text { Bajaj \& Sharma } \\
\text { [82] }\end{array}$ & $\begin{array}{l}\text { Smart education with } \\
\text { artificial intelligence-based } \\
\text { determination of learning } \\
\text { styles }\end{array}$ & $\begin{array}{l}\text { Procedia Computer } \\
\text { Science }\end{array}$ & $\begin{array}{l}\text { To develop a framework } \\
\text { for student learning } \\
\text { styles using learning } \\
\text { models and ratification } \\
\text { intelligence. }\end{array}$ & $\begin{array}{l}\text { Develops a framework for } \\
\text { AI to improve adaptivity } \\
\text { in teaching. }\end{array}$ & Society & $\begin{array}{l}\text { LB } \\
\text { KB } \\
\text { PM } \\
\text { ML } \\
\text { EI } \\
\text { SO }\end{array}$ & $\begin{array}{l}\text { ES } \\
\text { DN } \\
\text { PP } \\
\text { NN } \\
\text { DAI } \\
\text { EA }\end{array}$ & $\begin{array}{l}\text { FS } \\
\text { BN } \\
\text { BPS } \\
\text { MAS } \\
\text { SI } \\
\text { GA }\end{array}$ & $\begin{array}{l}\text { Smart } \\
\text { Education }\end{array}$ \\
\hline $\begin{array}{l}\text { Bennett \& Hauser } \\
\text { [137] }\end{array}$ & $\begin{array}{l}\text { Artificial intelligence } \\
\text { framework for simulating } \\
\text { clinical decision-making }\end{array}$ & $\begin{array}{l}\text { Artificial } \\
\text { Intelligence in } \\
\text { Medicine }\end{array}$ & $\begin{array}{l}\text { To developing a } \\
\text { framework for using AI } \\
\text { to address healthcare } \\
\text { challenges. }\end{array}$ & $\begin{array}{l}\text { Describes how AI could } \\
\text { lead to improvements in } \\
\text { diagnosis and treatment. }\end{array}$ & Society & $\begin{array}{l}\text { PM } \\
\text { EI }\end{array}$ & DAI & MAS & Smart Health \\
\hline
\end{tabular}


Table A1. Cont.

\begin{tabular}{|c|c|c|c|c|c|c|c|c|c|}
\hline Author & Title & Journal & Aim & Relevance & Domain & Paradigm & Application & Method & Technology \\
\hline Bose [78] & $\begin{array}{l}\text { Artificial intelligence } \\
\text { techniques in smart grid } \\
\text { and renewable energy } \\
\text { systems }\end{array}$ & $\begin{array}{l}\text { Proceedings of the } \\
\text { IEEE }\end{array}$ & $\begin{array}{l}\text { To explain application } \\
\text { of AI in smart grids and } \\
\text { renewable energy } \\
\text { systems }\end{array}$ & $\begin{array}{l}\text { Provides insights into the } \\
\text { use of smart grids for } \\
\text { prediction, estimation and } \\
\text { control of power systems. }\end{array}$ & Environment & $\begin{array}{l}\text { LB } \\
\text { KB } \\
\text { ML }\end{array}$ & $\begin{array}{l}\text { ES } \\
\text { NN } \\
\text { AS }\end{array}$ & $\begin{array}{l}\text { FS } \\
\text { DL }\end{array}$ & Smart Energy \\
\hline Brady [103] & $\begin{array}{l}\text { The challenge of big data } \\
\text { and data science }\end{array}$ & $\begin{array}{l}\text { Annual Review of } \\
\text { Political Science }\end{array}$ & $\begin{array}{l}\text { To identify innovative } \\
\text { methods for answering } \\
\text { previously } \\
\text { hard-to-tackle questions } \\
\text { about society. }\end{array}$ & $\begin{array}{l}\text { Provides insights into } \\
\text { how AI can improve } \\
\text { decision-making, } \\
\text { efficiency, and reduce } \\
\text { errors and uncertainty. }\end{array}$ & Economy & ML & $\mathrm{NN}$ & $\mathrm{n} / \mathrm{a}$ & $\mathrm{n} / \mathrm{a}$ \\
\hline Braun et al. [83] & $\begin{array}{l}\text { Security and privacy } \\
\text { challenges in smart cities }\end{array}$ & $\begin{array}{l}\text { Sustainable Cities } \\
\text { and Society }\end{array}$ & $\begin{array}{l}\text { To identify possible } \\
\text { solutions to five smart } \\
\text { city challenges. }\end{array}$ & $\begin{array}{l}\text { Provides insights into the } \\
\text { use of AI for cyber } \\
\text { security. }\end{array}$ & Governance & ML & $\mathrm{NN}$ & $\mathrm{n} / \mathrm{a}$ & $\begin{array}{l}\text { Smart } \\
\text { Surveillance }\end{array}$ \\
\hline Bui \& Jung [104] & $\begin{array}{l}\text { Computational } \\
\text { negotiation-based edge } \\
\text { analytics for smart objects }\end{array}$ & $\begin{array}{l}\text { Information } \\
\text { Sciences }\end{array}$ & $\begin{array}{l}\text { To develop a } \\
\text { computational } \\
\text { negotiation approach on } \\
\text { IoT systems where } \\
\text { distributed edge devices } \\
\text { can make their own } \\
\text { decisions. }\end{array}$ & $\begin{array}{l}\text { Describes the potential for } \\
\text { AI and smart traffic } \\
\text { control systems to } \\
\text { communicate with } \\
\text { connected-AV, and make } \\
\text { real-time decisions to } \\
\text { improve the efficiency of } \\
\text { the transport network. }\end{array}$ & Economy & $\begin{array}{l}\text { ML } \\
\text { EI }\end{array}$ & AS & $\mathrm{n} / \mathrm{a}$ & IoT \\
\hline Cai et al. [105] & $\begin{array}{l}\text { Deep learning-based video } \\
\text { system for accurate and } \\
\text { real-time parking } \\
\text { measurement }\end{array}$ & $\begin{array}{l}\text { IEEE Internet of } \\
\text { Things Journal }\end{array}$ & $\begin{array}{l}\text { To develop an accurate } \\
\text { and real-time video } \\
\text { system for future IoT } \\
\text { and smart cities } \\
\text { applications }\end{array}$ & $\begin{array}{l}\text { Discusses using AI for } \\
\text { real-time measurements } \\
\text { to make parking more } \\
\text { efficient. }\end{array}$ & Environment & ML & NN & DL & $\begin{array}{l}\text { IoT } \\
\text { Smart Parking }\end{array}$ \\
\hline Casares [84] & $\begin{array}{l}\text { The brain of the future and } \\
\text { the viability of democratic } \\
\text { governance }\end{array}$ & Futures & $\begin{array}{l}\text { To identify AI } \\
\text { implications and the } \\
\text { potential challenges in } \\
\text { democratic societies. }\end{array}$ & $\begin{array}{l}\text { Identifies the potential for } \\
\text { AI to contribute to public } \\
\text { governance. }\end{array}$ & Governance & ML & $\mathrm{NN}$ & DL & $\mathrm{n} / \mathrm{a}$ \\
\hline $\begin{array}{l}\text { Castelli et al. } \\
\text { [144] }\end{array}$ & $\begin{array}{l}\text { Predicting per capita violent } \\
\text { crimes in urban areas }\end{array}$ & $\begin{array}{l}\text { Journal of Ambient } \\
\text { Intelligence and } \\
\text { Humanized } \\
\text { Computing }\end{array}$ & $\begin{array}{l}\text { To combine a version of } \\
\text { genetic programming } \\
\text { with a local search } \\
\text { method }\end{array}$ & $\begin{array}{l}\text { Describes the use of AI in } \\
\text { crime prediction and } \\
\text { optimal allocation of law } \\
\text { enforcement. }\end{array}$ & Governance & SO & EA & GA & $\mathrm{n} / \mathrm{a}$ \\
\hline $\begin{array}{l}\text { Chassignol et al. } \\
\text { [85] }\end{array}$ & $\begin{array}{l}\text { Artificial Intelligence trends } \\
\text { in education }\end{array}$ & $\begin{array}{l}\text { Procedia Computer } \\
\text { Science }\end{array}$ & $\begin{array}{l}\text { To identify the } \\
\text { prospective impact of } \\
\text { AI technologies on the } \\
\text { study process. }\end{array}$ & $\begin{array}{l}\text { Identifies the potential for } \\
\text { AI to develop innovative } \\
\text { teaching methods, and } \\
\text { improve student } \\
\text { outcomes. }\end{array}$ & Society & ML & $\mathrm{NN}$ & $\mathrm{n} / \mathrm{a}$ & $\begin{array}{l}\text { Smart } \\
\text { Education } \\
\text { Augment. } \\
\text { Reality } \\
\text { Virtual Reality }\end{array}$ \\
\hline $\begin{array}{l}\text { Chatterjee et al. } \\
\text { [164] }\end{array}$ & $\begin{array}{l}\text { Success of IoT in smart } \\
\text { cities of India }\end{array}$ & $\begin{array}{l}\text { Government } \\
\text { Information } \\
\text { Quarterly }\end{array}$ & $\begin{array}{l}\text { To combine IoT with AI } \\
\text { in smart machines to } \\
\text { simulate intelligent } \\
\text { behavior and assist } \\
\text { autonomous decision } \\
\text { making. }\end{array}$ & $\begin{array}{l}\text { Describes the use of AI to } \\
\text { obtain data from IoT to } \\
\text { understand acceptance of } \\
\text { new technologies. }\end{array}$ & Governance & $\mathrm{n} / \mathrm{a}$ & $\mathrm{n} / \mathrm{a}$ & $\mathrm{n} / \mathrm{a}$ & $\begin{array}{l}\text { IoT } \\
\text { ICT }\end{array}$ \\
\hline
\end{tabular}


Table A1. Cont.

\begin{tabular}{|c|c|c|c|c|c|c|c|c|c|}
\hline Author & Title & Journal & Aim & Relevance & Domain & Paradigm & Application & Method & Technology \\
\hline Chau [69] & $\begin{array}{l}\text { A review on integration of } \\
\text { artificial intelligence into } \\
\text { water quality modelling }\end{array}$ & $\begin{array}{l}\text { Marine Pollution } \\
\text { Bulletin }\end{array}$ & $\begin{array}{l}\text { To reviewing the current } \\
\text { state-of-the-art AI and } \\
\text { its application in water } \\
\text { quality modelling. }\end{array}$ & $\begin{array}{l}\text { Provides insights into } \\
\text { how AI can be used to } \\
\text { develop more accurate } \\
\text { water quality modelling }\end{array}$ & Environment & $\begin{array}{l}\text { LB } \\
\text { KB } \\
\text { ML } \\
\text { SO }\end{array}$ & $\begin{array}{l}\text { ILP } \\
\text { ES } \\
\text { NN } \\
\text { EA }\end{array}$ & $\begin{array}{l}\text { FS } \\
\text { DL } \\
\text { GA }\end{array}$ & $\begin{array}{l}\text { Smart } \\
\text { Environment }\end{array}$ \\
\hline Chen et al. [107] & $\begin{array}{l}\text { An intelligent robust } \\
\text { networking mechanism for } \\
\text { the internet of things }\end{array}$ & $\begin{array}{l}\text { IEEE } \\
\text { Communications } \\
\text { Magazine }\end{array}$ & $\begin{array}{l}\text { To enhance the } \\
\text { robustness of IoT } \\
\text { topologies }\end{array}$ & $\begin{array}{l}\text { Identifies how AI can } \\
\text { reduce uncertainty in } \\
\text { relation to robustness } \\
\text { optimization, improve the } \\
\text { cost and efficiency of } \\
\text { network communications } \\
\text { and protect against } \\
\text { cyber-attacks. }\end{array}$ & Economy & $\begin{array}{l}\text { ML } \\
\text { SO }\end{array}$ & $\begin{array}{l}\mathrm{NN} \\
\mathrm{EA}\end{array}$ & $\begin{array}{l}\text { DL } \\
\text { GA }\end{array}$ & $\begin{array}{l}\text { IoT } \\
\text { Smart Energy }\end{array}$ \\
\hline Chen et al. [106] & Cognitive-LPWAN & $\begin{array}{l}\text { IEEE Transactions } \\
\text { on Green } \\
\text { Communications } \\
\text { and Networking }\end{array}$ & $\begin{array}{l}\text { To provide information } \\
\text { regarding current } \\
\text { wireless communication } \\
\text { technologies, and other } \\
\text { technologies }\end{array}$ & $\begin{array}{l}\text { Provides insights into } \\
\text { how AI can be used to } \\
\text { improve communication } \\
\text { networks }\end{array}$ & Economy & ML & $\mathrm{NN}$ & DL & IoT \\
\hline Chmiel [74] & INSIGMA & $\begin{array}{l}\text { Multimedia Tools } \\
\text { and Applications }\end{array}$ & $\begin{array}{l}\text { To investigate using } \\
\text { intelligent transport } \\
\text { systems for improving } \\
\text { safety, mobility and } \\
\text { environmental } \\
\text { outcomes. }\end{array}$ & $\begin{array}{l}\text { Describes using } \\
\text { intelligent transport } \\
\text { systems to improve } \\
\text { congestion. }\end{array}$ & Environment & $\begin{array}{l}\text { PM } \\
\text { ML }\end{array}$ & $\mathrm{CV}$ & $\begin{array}{l}\text { IR } \\
\text { MV }\end{array}$ & $\begin{array}{l}\text { Smart } \\
\text { Transport }\end{array}$ \\
\hline Chui et al. [86] & $\begin{array}{l}\text { Energy sustainability in } \\
\text { smart cities }\end{array}$ & Energies & $\begin{array}{l}\text { To show ways in which } \\
\text { AI can support energy } \\
\text { sustainability. }\end{array}$ & $\begin{array}{l}\text { Provides insights in the } \\
\text { use of AI to monitor } \\
\text { energy consumption. }\end{array}$ & Environment & $\begin{array}{l}\text { ML } \\
\text { SO }\end{array}$ & EA & GA & $\begin{array}{l}\text { IoT } \\
\text { Smart Energy }\end{array}$ \\
\hline Cortes et al. [136] & $\begin{array}{l}\text { Artificial intelligence and } \\
\text { environmental decision } \\
\text { support systems }\end{array}$ & $\begin{array}{l}\text { Applied } \\
\text { intelligence }\end{array}$ & $\begin{array}{l}\text { To provide an overview } \\
\text { of the impact of AI on } \\
\text { environmental decision } \\
\text { support systems. }\end{array}$ & $\begin{array}{l}\text { Identifies how AI can } \\
\text { assist in environmental } \\
\text { decision-making }\end{array}$ & Environment & $\begin{array}{l}\text { LB } \\
\text { KB } \\
\text { PM }\end{array}$ & $\begin{array}{l}\text { Expert System } \\
\text { DN }\end{array}$ & $\mathrm{n} / \mathrm{a}$ & $\begin{array}{l}\text { Smart } \\
\text { Environment }\end{array}$ \\
\hline Cui et al. [108] & $\begin{array}{l}\text { Big data analytics and } \\
\text { network calculus enabling } \\
\text { intelligent management of } \\
\text { autonomous vehicles in a } \\
\text { smart city }\end{array}$ & $\begin{array}{l}\text { IEEE Internet of } \\
\text { Things Journal }\end{array}$ & $\begin{array}{l}\text { To develop a new online } \\
\text { AV fleet management } \\
\text { scheme that controls } \\
\text { congestion in cities. }\end{array}$ & $\begin{array}{l}\text { Discusses using } \mathrm{AI} \text { to } \\
\text { reduce travel time in } \mathrm{AV} \text {. }\end{array}$ & Environment & ML & $\mathrm{n} / \mathrm{a}$ & $\mathrm{n} / \mathrm{a}$ & $\begin{array}{l}\text { IoT } \\
\text { Smart } \\
\text { Transport }\end{array}$ \\
\hline De Paz et al. [75] & $\begin{array}{l}\text { Intelligent system for } \\
\text { lighting control in smart } \\
\text { cities }\end{array}$ & $\begin{array}{l}\text { Information } \\
\text { Sciences }\end{array}$ & $\begin{array}{l}\text { To develop a new } \\
\text { intelligent lighting } \\
\text { system for cities. }\end{array}$ & $\begin{array}{l}\text { Describes the use of AI to } \\
\text { control public lighting to } \\
\text { optimize power usage. }\end{array}$ & Environment & $\begin{array}{l}\text { PM } \\
\text { ML } \\
\text { EI }\end{array}$ & $\begin{array}{l}\mathrm{CV} \\
\mathrm{NN} \\
\mathrm{DAI}\end{array}$ & $\begin{array}{l}\text { IR } \\
\text { MV } \\
\text { MAS }\end{array}$ & Smart Energy \\
\hline
\end{tabular}


Table A1. Cont.

\begin{tabular}{|c|c|c|c|c|c|c|c|c|c|}
\hline Author & Title & Journal & Aim & Relevance & Domain & Paradigm & Application & Method & Technology \\
\hline $\begin{array}{l}\text { Desouza et al. } \\
\text { [109] }\end{array}$ & $\begin{array}{l}\text { Designing, developing, and } \\
\text { deploying artificial } \\
\text { intelligence systems }\end{array}$ & Business Horizons & $\begin{array}{l}\text { To reflect and provide } \\
\text { insights from AI projects } \\
\text { in the public sector. }\end{array}$ & $\begin{array}{l}\text { Discusses how cognitive } \\
\text { computing systems are } \\
\text { able simulate human } \\
\text { thought and learning and } \\
\text { can be used for fraud } \\
\text { detection, } \\
\text { decision-support, and } \\
\text { online assistance. }\end{array}$ & Governance & ML & $\mathrm{NN}$ & DL & $\mathrm{n} / \mathrm{a}$ \\
\hline Devedzic [147] & $\begin{array}{l}\text { Web intelligence and } \\
\text { artificial intelligence in } \\
\text { education }\end{array}$ & $\begin{array}{l}\text { Educational } \\
\text { Technology \& } \\
\text { Society }\end{array}$ & $\begin{array}{l}\text { To survey important } \\
\text { aspects of web } \\
\text { intelligence in the } \\
\text { context of AI in } \\
\text { education }\end{array}$ & $\begin{array}{l}\text { Discusses how AI can } \\
\text { improve adaptability in } \\
\text { learning environments, } \\
\text { and create more } \\
\text { comfortable learning } \\
\text { environments. }\end{array}$ & Society & EI & DAI & $\mathrm{ABM}$ & $\begin{array}{l}\text { Smart } \\
\text { Education }\end{array}$ \\
\hline Din et al. [110] & $\begin{array}{l}\text { Machine learning in the } \\
\text { internet of things }\end{array}$ & $\begin{array}{l}\text { Future Generation } \\
\text { Computer Systems }\end{array}$ & $\begin{array}{l}\text { To examine different IoT } \\
\text { based machine learning } \\
\text { mechanisms }\end{array}$ & $\begin{array}{l}\text { Identifies machine } \\
\text { learning as an important } \\
\text { component for IoT } \\
\text { particularly regarding } \\
\text { data management. }\end{array}$ & Economy & ML & $\mathrm{NN}$ & $\mathrm{DL}$ & IoT \\
\hline $\begin{array}{l}\text { Dobrescu \& } \\
\text { Dobrescu [87] }\end{array}$ & Artificial intelligence (AI) & $\begin{array}{l}\text { Global Economic } \\
\text { Observer }\end{array}$ & $\begin{array}{l}\text { To present trends, } \\
\text { analyses and } \\
\text { perceptions of AI. }\end{array}$ & $\begin{array}{l}\text { Presents the benefits and } \\
\text { disadvantages of } \\
\text { integration of AI into all } \\
\text { areas of socio-economic } \\
\text { life }\end{array}$ & Society & $\begin{array}{l}\text { PM } \\
\text { ML }\end{array}$ & $\begin{array}{l}\text { NLP } \\
\text { CV } \\
\text { NN }\end{array}$ & $\begin{array}{l}\text { DL } \\
\text { IR } \\
\text { NLU } \\
\text { NLG }\end{array}$ & $n / a$ \\
\hline Dong et al. [111] & $\begin{array}{l}\text { Energy-efficient fair } \\
\text { cooperation fog computing } \\
\text { in mobile edge networks for } \\
\text { smart city }\end{array}$ & $\begin{array}{l}\text { IEEE Internet of } \\
\text { Things Journal }\end{array}$ & $\begin{array}{l}\text { To examine the } \\
\text { convexity of the } \\
\text { optimization problem } \\
\text { and design a fairness } \\
\text { cooperation algorithm. }\end{array}$ & $\begin{array}{l}\text { Identifies IoT and AI as } \\
\text { two of the most important } \\
\text { technologies to help } \\
\text { enable smart cities } \\
\text { particularly regarding big } \\
\text { data analysis. }\end{array}$ & Economy & ML & $\mathrm{n} / \mathrm{a}$ & $\mathrm{n} / \mathrm{a}$ & IoT \\
\hline $\begin{array}{l}\text { Drigas \& } \\
\text { Ioannidou [71] }\end{array}$ & $\begin{array}{l}\text { Artificial intelligence in } \\
\text { special education }\end{array}$ & $\begin{array}{l}\text { International } \\
\text { Journal of } \\
\text { Engineering } \\
\text { Education }\end{array}$ & $\begin{array}{l}\text { To review studies that } \\
\text { use AI methods in } \\
\text { making accurate } \\
\text { diagnosis. }\end{array}$ & $\begin{array}{l}\text { Discusses how AI can } \\
\text { stimulate problem } \\
\text { solving, particularly in } \\
\text { special needs students, to } \\
\text { enhance the way children } \\
\text { interact with their } \\
\text { environment. }\end{array}$ & Society & $\begin{array}{l}\text { LB } \\
\text { KB } \\
\text { ML }\end{array}$ & $\begin{array}{l}\text { ES } \\
\text { NN }\end{array}$ & FS & $\begin{array}{l}\text { Smart } \\
\text { Education }\end{array}$ \\
\hline $\begin{array}{l}\text { Edwards et al. } \\
\text { [88] }\end{array}$ & $\begin{array}{l}\text { I, teacher: using artificial } \\
\text { intelligence (AI) and social } \\
\text { robots in communication } \\
\text { and instruction }\end{array}$ & $\begin{array}{l}\text { Communication } \\
\text { Education }\end{array}$ & $\begin{array}{l}\text { To argue the importance } \\
\text { of using AI in teaching. }\end{array}$ & $\begin{array}{l}\text { Examines the role of } \\
\text { teacher in an AI enabled } \\
\text { education system. }\end{array}$ & Society & ML & NLP & NLG & $\begin{array}{l}\text { Social Robots } \\
\text { Smart } \\
\text { Education }\end{array}$ \\
\hline
\end{tabular}


Table A1. Cont.

\begin{tabular}{|c|c|c|c|c|c|c|c|c|c|}
\hline Author & Title & Journal & Aim & Relevance & Domain & Paradigm & Application & Method & Technology \\
\hline $\begin{array}{l}\text { Eldrandaly et al. } \\
\text { [148] }\end{array}$ & $\begin{array}{l}\text { PTZ-surveillance coverage } \\
\text { based on artificial } \\
\text { intelligence for smart cities }\end{array}$ & $\begin{array}{l}\text { International } \\
\text { Journal of } \\
\text { Information } \\
\text { Management }\end{array}$ & $\begin{array}{l}\text { To develop AI } \\
\text { algorithm for adjusting } \\
\text { the orientation of } \\
\text { pan-tilt-zoom } \\
\text { surveillance cameras. }\end{array}$ & $\begin{array}{l}\text { Discusses the use of AI } \\
\text { technology to } \\
\text { automatically improve } \\
\text { the field of view of } \\
\text { surveillance cameras }\end{array}$ & Governance & EI & DAI & SI & $\begin{array}{l}\text { IoT } \\
\text { Smart } \\
\text { Surveillance }\end{array}$ \\
\hline Falco et al. [162] & $\begin{array}{l}\text { A master attack } \\
\text { methodology for an } \\
\text { AI-based automated attack } \\
\text { planner for smart cities }\end{array}$ & IEEE Access & $\begin{array}{l}\text { To identify solutions for } \\
\text { cyber safety of critical } \\
\text { infrastructure. }\end{array}$ & $\begin{array}{l}\text { Identifies the potential for } \\
\text { automated tools to } \\
\text { evaluate cyber threats to } \\
\text { infrastructure. }\end{array}$ & Governance & $\mathrm{n} / \mathrm{a}$ & $\mathrm{n} / \mathrm{a}$ & $\mathrm{n} / \mathrm{a}$ & IoT \\
\hline Feng \& Xu [63] & $\begin{array}{l}\text { Hybrid artificial intelligence } \\
\text { approach to urban planning }\end{array}$ & Expert Systems & $\begin{array}{l}\text { To present a hybrid AI } \\
\text { system for use in urban } \\
\text { planning. }\end{array}$ & $\begin{array}{l}\text { Describers how AI can } \\
\text { assist with } \\
\text { knowledge-based } \\
\text { decision making. }\end{array}$ & Environment & $\begin{array}{l}\text { LB } \\
\text { KB } \\
\text { ML }\end{array}$ & $\begin{array}{l}\text { ES } \\
\text { NN }\end{array}$ & $\begin{array}{l}\text { FS } \\
\text { DL }\end{array}$ & $\mathrm{n} / \mathrm{a}$ \\
\hline $\begin{array}{l}\text { Fernández et al. } \\
\text { [138] }\end{array}$ & $\begin{array}{l}\text { An intelligent surveillance } \\
\text { platform for large } \\
\text { metropolitan areas with } \\
\text { dense sensor deployment }\end{array}$ & Sensors & $\begin{array}{l}\text { To maximize the } \\
\text { number of deployable } \\
\text { units in surveillance } \\
\text { while minimizing costs. }\end{array}$ & $\begin{array}{l}\text { Presents an intelligent } \\
\text { surveillance platform for } \\
\text { surveillance of public } \\
\text { spaces }\end{array}$ & Governance & PM & $\mathrm{CV}$ & IR & $\begin{array}{l}\text { Smart } \\
\text { Surveillance }\end{array}$ \\
\hline $\begin{array}{l}\text { Garlík } \\
\text { [79] }\end{array}$ & $\begin{array}{l}\text { The application of artificial } \\
\text { Intelligence in the process } \\
\text { of optimizing energy } \\
\text { consumption in intelligent } \\
\text { areas }\end{array}$ & $\begin{array}{l}\text { Neural Network } \\
\text { World }\end{array}$ & $\begin{array}{l}\text { To monitor and control } \\
\text { the operation of selected } \\
\text { smart objects. }\end{array}$ & $\begin{array}{l}\text { Discusses the use of AI for } \\
\text { energy optimization }\end{array}$ & Environment & $\begin{array}{l}\text { ML } \\
\text { SO }\end{array}$ & $\begin{array}{l}\mathrm{NN} \\
\mathrm{EA}\end{array}$ & GA & Smart Energy \\
\hline Guilherme [153] & AI and education & AI \& Society & $\begin{array}{l}\text { To identify use of AI in } \\
\text { assessing education and } \\
\text { the relations between } \\
\text { teachers and students, } \\
\text { and students and } \\
\text { students. }\end{array}$ & $\begin{array}{l}\text { Identifies new roles for } \\
\text { teachers in education. }\end{array}$ & Society & $\mathrm{n} / \mathrm{a}$ & $\mathrm{n} / \mathrm{a}$ & $\mathrm{n} / \mathrm{a}$ & $\begin{array}{l}\text { Smart } \\
\text { Education }\end{array}$ \\
\hline Guo \& Li [89] & $\begin{array}{l}\text { The application of medical } \\
\text { artificial intelligence } \\
\text { technology in rural areas of } \\
\text { developing countries }\end{array}$ & Health Equity & $\begin{array}{l}\text { To review the literature } \\
\text { concerning the } \\
\text { prospects of medical AI } \\
\text { technology, and } \\
\text { application in rural } \\
\text { areas. }\end{array}$ & $\begin{array}{l}\text { Identifies AI as a means to } \\
\text { improve equality between } \\
\text { rural and urban health } \\
\text { areas. }\end{array}$ & Society & ML & NN & $\mathrm{n} / \mathrm{a}$ & Smart Health \\
\hline Guo et al. [90] & $\begin{array}{l}\text { Artificial intelligence-based } \\
\text { semantic internet of things } \\
\text { in a user-centric smart city }\end{array}$ & Sensors & $\begin{array}{l}\text { To discuss the links } \\
\text { between AI and IoT in } \\
\text { the context of smart city }\end{array}$ & $\begin{array}{l}\text { Describes how AI can } \\
\text { contribute to } \\
\text { environmental } \\
\text { monitoring. }\end{array}$ & Environment & $\begin{array}{l}\text { PM } \\
\text { ML }\end{array}$ & $\begin{array}{l}\text { DN } \\
\text { NN }\end{array}$ & $\begin{array}{l}\text { BN } \\
\text { DL }\end{array}$ & IoT \\
\hline Håkansson [91] & $\begin{array}{l}\text { Ipsum: an approach to } \\
\text { smart volatile } \\
\text { ICT-infrastructures for } \\
\text { smart cities and } \\
\text { communities }\end{array}$ & $\begin{array}{l}\text { Procedia Computer } \\
\text { Science }\end{array}$ & $\begin{array}{l}\text { To create smart volatile } \\
\text { ICT infrastructures in } \\
\text { cities. }\end{array}$ & $\begin{array}{l}\text { Discusses using AI for } \\
\text { customized health care. }\end{array}$ & Society & ML & $\mathrm{n} / \mathrm{a}$ & $\mathrm{n} / \mathrm{a}$ & $\begin{array}{l}\text { IoT } \\
\text { ICT } \\
\text { Cyber-Physical } \\
\text { Smart } \\
\text { Infrastructure }\end{array}$ \\
\hline
\end{tabular}


Table A1. Cont.

\begin{tabular}{|c|c|c|c|c|c|c|c|c|c|}
\hline Author & Title & Journal & Aim & Relevance & Domain & Paradigm & Application & Method & Technology \\
\hline $\begin{array}{l}\text { Hanson \& } \\
\text { Marshall [67] }\end{array}$ & $\begin{array}{l}\text { Artificial intelligence } \\
\text { applications in the intensive } \\
\text { care unit }\end{array}$ & $\begin{array}{l}\text { Critical Care } \\
\text { Medicine }\end{array}$ & $\begin{array}{l}\text { To review application of } \\
\mathrm{AI} \text { in intensive care. }\end{array}$ & $\begin{array}{l}\text { Describes how AI as a } \\
\text { monitoring tool can assist } \\
\text { intensive care providers } \\
\text { and resulting in reduced } \\
\text { costs and improved } \\
\text { patient outcomes }\end{array}$ & Society & $\begin{array}{l}\text { LB } \\
\text { KB } \\
\text { ML } \\
\text { SO }\end{array}$ & $\begin{array}{l}\text { ES } \\
\text { NN } \\
\text { EA }\end{array}$ & $\begin{array}{l}\text { FS } \\
\text { DL } \\
\text { GA }\end{array}$ & Smart Health \\
\hline Hariri et al. [112] & $\begin{array}{l}\text { Uncertainty in big data } \\
\text { analytics }\end{array}$ & Journal of Big Data & $\begin{array}{l}\text { To review big data } \\
\text { analytics. }\end{array}$ & $\begin{array}{l}\text { Identifies AI techniques } \\
\text { as beneficial to the } \\
\text { accurate and timely } \\
\text { analysis of big data. }\end{array}$ & Economy & $\begin{array}{l}\text { LB } \\
\text { KB } \\
\text { PM } \\
\text { ML } \\
\text { SO }\end{array}$ & $\begin{array}{l}\text { ES } \\
\text { DN } \\
\text { EA }\end{array}$ & $\begin{array}{l}\text { FS } \\
\text { BN }\end{array}$ & IoT \\
\hline $\begin{array}{l}\text { Ibrahim et al. } \\
\text { [113] }\end{array}$ & $\begin{array}{l}\text { URBAN-i: from urban } \\
\text { scenes to mapping slums, } \\
\text { transport modes, and } \\
\text { pedestrians in cities using } \\
\text { deep learning and } \\
\text { computer vision }\end{array}$ & $\begin{array}{l}\text { Environment and } \\
\text { Planning B }\end{array}$ & $\begin{array}{l}\text { To develop framework } \\
\text { for multipurpose } \\
\text { realistic-dynamic urban } \\
\text { modelling using deep } \\
\text { CNN }\end{array}$ & $\begin{array}{l}\text { Describes using deep } \\
\text { learning to differentiate } \\
\text { spatial structures. }\end{array}$ & Environment & $\begin{array}{l}\mathrm{PM} \\
\mathrm{ML}\end{array}$ & $\begin{array}{l}\mathrm{CV} \\
\mathrm{NN}\end{array}$ & $\begin{array}{l}\text { IR } \\
\text { DL }\end{array}$ & $\mathrm{n} / \mathrm{a}$ \\
\hline $\begin{array}{l}\text { Inclezan \& } \\
\text { Prádanos [156] }\end{array}$ & $\begin{array}{l}\text { Overview: a critical view } \\
\text { on smart cities and AI }\end{array}$ & $\begin{array}{l}\text { Journal of Artificial } \\
\text { Intelligence } \\
\text { Research }\end{array}$ & $\begin{array}{l}\text { To advocate using AI to } \\
\text { solve urban problems. }\end{array}$ & $\begin{array}{l}\text { Reflects, critically, on the } \\
\text { optimistic viewpoint of } \\
\text { AI in relation to its } \\
\text { potential to respond to } \\
\text { urban problems (e.g. } \\
\text { congestion, population } \\
\text { growth, energy efficiency, } \\
\text { environmental } \\
\text { degradation and safety). }\end{array}$ & Environment & $\mathrm{n} / \mathrm{a}$ & $\mathrm{n} / \mathrm{a}$ & $\mathrm{n} / \mathrm{a}$ & $\mathrm{n} / \mathrm{a}$ \\
\hline Iqbal et al. [114] & $\begin{array}{l}\text { Intelligent remote } \\
\text { monitoring of parking } \\
\text { spaces using licensed and } \\
\text { unlicensed wireless } \\
\text { technologies }\end{array}$ & IEEE Network & $\begin{array}{l}\text { To develop an } \\
\text { intelligent parking } \\
\text { system model }\end{array}$ & $\begin{array}{l}\text { Describes using AI for } \\
\text { parking utilization and } \\
\text { optimization. }\end{array}$ & Environment & $\begin{array}{l}\mathrm{PM} \\
\mathrm{ML}\end{array}$ & $\begin{array}{l}\mathrm{CV} \\
\mathrm{NN}\end{array}$ & $\begin{array}{l}\text { AR } \\
\text { IR } \\
\text { MV } \\
\text { DL }\end{array}$ & $\begin{array}{l}\text { IoT } \\
\text { Smart Parking }\end{array}$ \\
\hline Jha et al. [80] & Renewable energy & $\begin{array}{l}\text { Renewable and } \\
\text { Sustainable Energy } \\
\text { Reviews }\end{array}$ & $\begin{array}{l}\text { To summarize reviews } \\
\text { and state-of-the-art } \\
\text { research outcomes } \\
\text { related to renewable } \\
\text { energies }\end{array}$ & $\begin{array}{l}\text { Describes the use of AI to } \\
\text { achieve renewable energy } \\
\text { goals }\end{array}$ & Environment & $\begin{array}{l}\text { PM } \\
\text { ML } \\
\text { EI } \\
\text { SO }\end{array}$ & $\begin{array}{l}\text { DN } \\
\text { PP } \\
\text { NN } \\
\text { DAI } \\
\text { EA }\end{array}$ & $\begin{array}{l}\text { BN } \\
\text { BPS } \\
\text { GA } \\
\text { MAS } \\
\text { SI }\end{array}$ & Smart Energy \\
\hline Khalifa [161] & $\begin{array}{l}\text { Smart cities: opportunities, } \\
\text { challenges, and security } \\
\text { threats }\end{array}$ & $\begin{array}{l}\text { Journal of Strategic } \\
\text { Innovation and } \\
\text { Sustainability }\end{array}$ & $\begin{array}{l}\text { To discuss the } \\
\text { importance and } \\
\text { consequences of smart } \\
\text { city development. }\end{array}$ & $\begin{array}{l}\text { Identifies the opportunity } \\
\text { for AI and smart cities to } \\
\text { achieve better security } \\
\text { measures }\end{array}$ & Governance & $\mathrm{n} / \mathrm{a}$ & $\mathrm{n} / \mathrm{a}$ & $\mathrm{n} / \mathrm{a}$ & $\mathrm{n} / \mathrm{a}$ \\
\hline $\begin{array}{l}\text { Kopytko et al. } \\
\text { [92] }\end{array}$ & $\begin{array}{l}\text { Smart home and artificial } \\
\text { intelligence as environment } \\
\text { for the implementation of } \\
\text { new technologies }\end{array}$ & Path of Science & $\begin{array}{l}\text { To determine smart } \\
\text { homes and AI as } \\
\text { combined innovative } \\
\text { tools. }\end{array}$ & $\begin{array}{l}\text { Provides insights into the } \\
\text { use of AI in smart homes } \\
\text { to achieve energy savings. }\end{array}$ & Environment & $\begin{array}{l}\text { LB } \\
\text { KB } \\
\text { ML } \\
\text { SO }\end{array}$ & $\begin{array}{l}\text { ES } \\
\text { NN } \\
\text { DAI } \\
\text { EA }\end{array}$ & $\begin{array}{l}\text { FS } \\
\text { DL } \\
\text { MAS } \\
\text { GA }\end{array}$ & $\begin{array}{l}\text { IoT } \\
\text { Smart Homes }\end{array}$ \\
\hline
\end{tabular}


Table A1. Cont.

\begin{tabular}{|c|c|c|c|c|c|c|c|c|c|}
\hline Author & Title & Journal & Aim & Relevance & Domain & Paradigm & Application & Method & Technology \\
\hline Kundu [115] & $\begin{array}{l}\text { Blockchain and trust in a } \\
\text { smart city }\end{array}$ & $\begin{array}{l}\text { Environment and } \\
\text { Urbanization Asia }\end{array}$ & $\begin{array}{l}\text { To provide insights into } \\
\text { institutions that can be } \\
\text { governed on blockchain } \\
\text { through smart contracts. }\end{array}$ & $\begin{array}{l}\text { Identifies trust as a } \\
\text { fundamental part of smart } \\
\text { city governance. }\end{array}$ & Governance & ML & $\mathrm{n} / \mathrm{a}$ & $\mathrm{n} / \mathrm{a}$ & $\begin{array}{l}\text { IoT } \\
\text { Blockchain }\end{array}$ \\
\hline Le et al. [116] & $\begin{array}{l}\text { A comparative study of } \\
\text { PSO-ANN, GA-ANN, } \\
\text { ICA-ANN, and ABC-ANN } \\
\text { in estimating the heating } \\
\text { load of buildings' energy } \\
\text { efficiency for smart city } \\
\text { planning }\end{array}$ & Applied Sciences & $\begin{array}{l}\text { To propose four new AI } \\
\text { techniques for } \\
\text { forecasting the heating } \\
\text { load of buildings }\end{array}$ & $\begin{array}{l}\text { Discusses the use of AI to } \\
\text { improve energy efficiency } \\
\text { in buildings }\end{array}$ & Environment & $\begin{array}{l}\text { ML } \\
\text { EI } \\
\text { SO }\end{array}$ & $\begin{array}{l}\text { NN } \\
\text { DAI } \\
\text { EA }\end{array}$ & $\begin{array}{l}\text { DL } \\
\text { SI } \\
\text { GA }\end{array}$ & Smart Energy \\
\hline Leung et al. [117] & $\begin{array}{l}\text { AI-based sensor } \\
\text { information fusion for } \\
\text { supporting deep supervised } \\
\text { learning }\end{array}$ & Sensors & $\begin{array}{l}\text { To present an AI-based } \\
\text { system which supports } \\
\text { deep supervised } \\
\text { learning of transport } \\
\text { data collected from } \\
\text { sensors }\end{array}$ & $\begin{array}{l}\text { Describes using AI-based } \\
\text { sensor to collect data from } \\
\text { multiple sources. }\end{array}$ & Environment & ML & $\mathrm{NN}$ & DL & $\begin{array}{l}\text { IoT } \\
\text { GNS } \\
\text { GPS } \\
\text { GIS }\end{array}$ \\
\hline Li et al. [118] & $\begin{array}{l}\text { Intelligent metasurface } \\
\text { imager and recognizer }\end{array}$ & $\begin{array}{l}\text { Light: Science \& } \\
\text { Applications }\end{array}$ & $\begin{array}{l}\text { To propose the use of a } \\
\text { smart metasurface } \\
\text { imager and recognizer, } \\
\text { empowered by a } \\
\text { network of ANN to } \\
\text { control data flow }\end{array}$ & $\begin{array}{l}\text { Identifies the potential for } \\
\text { AI enabled sensors and } \\
\text { other devices to monitor } \\
\text { health. }\end{array}$ & Society & ML & $\begin{array}{l}\mathrm{NN} \\
\mathrm{CV}\end{array}$ & $\begin{array}{l}\text { DL } \\
\text { MV }\end{array}$ & $\begin{array}{l}\text { IoT } \\
\text { Smart } \\
\text { Surveillance }\end{array}$ \\
\hline Liu et al. [93] & $\begin{array}{l}\text { Object tracking in vary } \\
\text { lighting conditions for fog } \\
\text { based intelligent } \\
\text { surveillance of public } \\
\text { spaces }\end{array}$ & IEEE Access & $\begin{array}{l}\text { To improve the } \\
\text { robustness and accuracy } \\
\text { of the correlation } \\
\text { filter-based trackers for } \\
\text { handling intense } \\
\text { illumination change. } \\
\text { To highlight the }\end{array}$ & $\begin{array}{l}\text { Describes the use of } \\
\text { intelligent surveillance } \\
\text { systems in detecting } \\
\text { abnormal circumstances, } \\
\text { identifying and tracking } \\
\text { targets. }\end{array}$ & Governance & $\begin{array}{l}\text { PM } \\
\text { ML }\end{array}$ & $\mathrm{CV}$ & $\begin{array}{l}\text { AR } \\
\text { IR } \\
\text { MV }\end{array}$ & $\begin{array}{l}\text { Smart } \\
\text { Surveillance }\end{array}$ \\
\hline Liu et al. [119] & $\begin{array}{l}\text { Modeling and simulation of } \\
\text { robot inverse dynamics } \\
\text { using LSTM-based deep } \\
\text { learning algorithm for } \\
\text { smart cities and factories }\end{array}$ & IEEE Access & $\begin{array}{l}\text { influence of the } \\
\text { hyper-parameter } \\
\text { settings on model } \\
\text { performance and to } \\
\text { explore the applicability } \\
\text { of the Long Short-Term } \\
\text { Memory model. }\end{array}$ & $\begin{array}{l}\text { Develops a model that } \\
\text { uses deep learning to } \\
\text { make robots more } \\
\text { responsive to uncertainty. }\end{array}$ & Economy & ML & $\mathrm{NN}$ & DL & Robotics \\
\hline $\begin{array}{l}\text { Lukowicz \& } \\
\text { Slusalle [94] }\end{array}$ & $\begin{array}{l}\text { How to avoid an } \mathrm{AI} \\
\text { interaction singularity }\end{array}$ & Interactions & $\begin{array}{l}\text { To advocate for AI } \\
\text { systems to focus on } \\
\text { enhancing human } \\
\text { cognitive capabilities, } \\
\text { and develop creativity, } \\
\text { inventiveness, and } \\
\text { intuition, trust, ethics, } \\
\text { and values }\end{array}$ & $\begin{array}{l}\text { Discusses goals required } \\
\text { to improve AI } \\
\text { decision-making. }\end{array}$ & Economy & $\begin{array}{l}\mathrm{PM} \\
\mathrm{ML}\end{array}$ & $\begin{array}{l}\text { CV } \\
\text { NLP }\end{array}$ & $\begin{array}{l}\text { IR } \\
\text { NLU }\end{array}$ & $\mathrm{n} / \mathrm{a}$ \\
\hline
\end{tabular}


Table A1. Cont.

\begin{tabular}{|c|c|c|c|c|c|c|c|c|c|}
\hline Author & Title & Journal & Aim & Relevance & Domain & Paradigm & Application & Method & Technology \\
\hline Lytras et al. [120] & $\begin{array}{l}\text { Data analytics in smart } \\
\text { healthcare }\end{array}$ & Applied Sciences & $\begin{array}{l}\text { To identify use of AI to } \\
\text { improve quality of life } \\
\text { and relieve medical } \\
\text { shortages }\end{array}$ & $\begin{array}{l}\text { Describes how smart } \\
\text { healthcare analytics can } \\
\text { improve quality of life for } \\
\text { patients. }\end{array}$ & Society & ML & $\mathrm{NN}$ & DL & $\begin{array}{l}\text { IoT } \\
\text { Smart Health }\end{array}$ \\
\hline Martins [95] & $\begin{array}{l}\text { Towards smart city } \\
\text { innovation }\end{array}$ & $\begin{array}{l}\text { Revista de } \\
\text { Tecnologia da } \\
\text { Informação e } \\
\text { Comunicação }\end{array}$ & $\begin{array}{l}\text { To analyze the impact } \\
\text { and perspectives on } \\
\text { adopting } \\
\text { software-defined } \\
\text { networking and AI for } \\
\text { smart city projects. }\end{array}$ & $\begin{array}{l}\text { Describes how cognitive } \\
\text { processing could allow } \\
\text { innovative solutions to } \\
\text { complex problems. }\end{array}$ & Governance & ML & $\mathrm{NN}$ & DL & $\mathrm{n} / \mathrm{a}$ \\
\hline $\begin{array}{l}\text { McArthur et al } \\
\text { [140] }\end{array}$ & $\begin{array}{l}\text { The roles of artificial } \\
\text { intelligence in education }\end{array}$ & $\begin{array}{l}\text { Journal of } \\
\text { Educational } \\
\text { Technology }\end{array}$ & $\begin{array}{l}\text { To summarize current } \\
\text { applications of ideas } \\
\text { from Al to education } \\
\text { field. }\end{array}$ & $\begin{array}{l}\text { Identifies future uses of } \\
\mathrm{AI} \text { in the education field. }\end{array}$ & Society & $\begin{array}{l}\mathrm{LB} \\
\mathrm{KB}\end{array}$ & ES & $\mathrm{n} / \mathrm{a}$ & $\begin{array}{l}\text { Smart } \\
\text { Education }\end{array}$ \\
\hline Meena et al. [145] & $\begin{array}{l}\text { Mobile power } \\
\text { infrastructure planning and } \\
\text { operational management } \\
\text { for smart city applications }\end{array}$ & Energy Procedia & $\begin{array}{l}\text { To maximize the profit } \\
\text { of utility and electric } \\
\text { vehicle owners. }\end{array}$ & $\begin{array}{l}\text { Provides insights into the } \\
\text { use of AI to optimize } \\
\text { energy consumption } \\
\text { particularly electrical } \\
\text { vehicles. }\end{array}$ & Environment & SO & EA & GA & IoT \\
\hline $\begin{array}{l}\text { Muhammad et al. } \\
\text { [121] }\end{array}$ & $\begin{array}{l}\text { Intelligent and } \\
\text { energy-efficient data } \\
\text { prioritization in green smart } \\
\text { cities }\end{array}$ & $\begin{array}{l}\text { IEEE } \\
\text { Communications } \\
\text { Magazine }\end{array}$ & $\begin{array}{l}\text { To highlight the key } \\
\text { challenges of data } \\
\text { prioritization, its future } \\
\text { requirements, and } \\
\text { propositions for } \\
\text { integration into green } \\
\text { smart cities }\end{array}$ & $\begin{array}{l}\text { Discusses the use of AI to } \\
\text { improve the efficiency of } \\
\text { data prioritization. }\end{array}$ & Environment & ML & $\mathrm{NN}$ & DL & IoT \\
\hline Nápoles et al. [96] & $\begin{array}{l}\text { MUSA-I: towards new } \\
\text { social tools for advanced } \\
\text { multi-modal transportation } \\
\text { in smart cities }\end{array}$ & $\begin{array}{l}\text { Multidisciplinary } \\
\text { Digital Publishing } \\
\text { Institute } \\
\text { Proceedings }\end{array}$ & $\begin{array}{l}\text { To describe the general } \\
\text { architecture and current } \\
\text { implementation of an } \\
\text { explicit multi-modal } \\
\text { transport demand } \\
\text { system for smart cities. }\end{array}$ & $\begin{array}{l}\text { Discusses using AI for } \\
\text { transport demand } \\
\text { management. }\end{array}$ & Environment & $\begin{array}{l}\text { PM } \\
\text { ML }\end{array}$ & $\mathrm{CV}$ & $\begin{array}{l}\text { AR } \\
\text { IR } \\
\text { MV }\end{array}$ & $\begin{array}{l}\text { Smart } \\
\text { Transport }\end{array}$ \\
\hline $\begin{array}{l}\text { Neuhauser et al. } \\
\text { [142] }\end{array}$ & $\begin{array}{l}\text { Using design science and } \\
\text { artificial intelligence to } \\
\text { improve health } \\
\text { communication }\end{array}$ & $\begin{array}{l}\text { Patient Education } \\
\text { and Counselling }\end{array}$ & $\begin{array}{l}\text { To describe how the use } \\
\text { of AI can improve the } \\
\text { effectiveness of health } \\
\text { communication. }\end{array}$ & $\begin{array}{l}\text { Discusses how AI can } \\
\text { improve the effectiveness } \\
\text { of communication in } \\
\text { health settings. }\end{array}$ & Society & $\begin{array}{l}\text { LB } \\
\text { KB }\end{array}$ & ES & $\mathrm{n} / \mathrm{a}$ & Smart Health \\
\hline $\begin{array}{l}\text { Noorbakhsh-Sabet } \\
\text { [122] }\end{array}$ & $\begin{array}{l}\text { Artificial intelligence } \\
\text { transforms the future of } \\
\text { healthcare }\end{array}$ & $\begin{array}{l}\text { The American } \\
\text { Journal of Medicine }\end{array}$ & $\begin{array}{l}\text { To review the } \\
\text { applications for } \\
\text { machine learning in } \\
\text { healthcare. }\end{array}$ & $\begin{array}{l}\text { Identifies AI potential to } \\
\text { increase learning and } \\
\text { decision support in the } \\
\text { health sector. }\end{array}$ & Society & ML & $\mathrm{NN}$ & $\mathrm{DL}$ & Smart Health \\
\hline
\end{tabular}


Table A1. Cont.

\begin{tabular}{|c|c|c|c|c|c|c|c|c|c|}
\hline Author & Title & Journal & Aim & Relevance & Domain & Paradigm & Application & Method & Technology \\
\hline Park et al. [123] & $\begin{array}{l}\text { Dependable fire detection } \\
\text { system with } \\
\text { multifunctional artificial } \\
\text { intelligence framework }\end{array}$ & Sensors & $\begin{array}{l}\text { To propose new fire } \\
\text { detection system using } \\
\text { a multifunctional AI } \\
\text { framework and data } \\
\text { transfer delay } \\
\text { minimization } \\
\text { mechanism. }\end{array}$ & $\begin{array}{l}\text { Describes how machine } \\
\text { learning can improve fire } \\
\text { detection systems. }\end{array}$ & Governance & ML & $\mathrm{NN}$ & DL & $\begin{array}{l}\text { IoT } \\
\text { Smart Fire } \\
\text { Detection }\end{array}$ \\
\hline Patel et al. [70] & $\begin{array}{l}\text { The coming of age of } \\
\text { artificial intelligence in } \\
\text { medicine }\end{array}$ & Path of Science & $\begin{array}{l}\text { To analyze discussions } \\
\text { which reflect on } \mathrm{AI} \text { in } \\
\text { the medical research } \\
\text { field. }\end{array}$ & $\begin{array}{l}\text { Discusses the use of AI in } \\
\text { medical care. }\end{array}$ & Society & $\begin{array}{l}\text { KB } \\
\text { PM } \\
\text { ML } \\
\text { EI }\end{array}$ & $\begin{array}{l}\text { ES } \\
\text { DN } \\
\text { NN } \\
\text { DAI }\end{array}$ & $\begin{array}{l}\text { BN } \\
\text { ABM }\end{array}$ & Smart Health \\
\hline $\begin{array}{l}\text { Pence } \\
\text { [152] }\end{array}$ & $\begin{array}{l}\text { Artificial intelligence in } \\
\text { higher education }\end{array}$ & $\begin{array}{l}\text { Journal of } \\
\text { Educational } \\
\text { Technology Systems }\end{array}$ & $\begin{array}{l}\text { To explore the use of AI } \\
\text { in education }\end{array}$ & $\begin{array}{l}\text { Identifies the need for } \\
\text { education to be adaptive } \\
\text { in the face of rapid } \\
\text { technology advances, and } \\
\text { changes to employment. }\end{array}$ & Society & $\mathrm{n} / \mathrm{a}$ & $\mathrm{n} / \mathrm{a}$ & $\mathrm{n} / \mathrm{a}$ & $\mathrm{n} / \mathrm{a}$ \\
\hline $\begin{array}{l}\text { Pieters } \\
{[141]}\end{array}$ & Explanation and trust & $\begin{array}{l}\text { Ethics and } \\
\text { Information } \\
\text { Technology }\end{array}$ & $\begin{array}{l}\text { To investigate the } \\
\text { relationship between } \\
\text { explanation and trust in } \\
\text { the context of AI }\end{array}$ & $\begin{array}{l}\text { Describes the importance } \\
\text { on online security for } \\
\text { trust in AI systems. }\end{array}$ & Governance & $\begin{array}{l}\mathrm{LB} \\
\mathrm{KB}\end{array}$ & ES & $\mathrm{n} / \mathrm{a}$ & $\mathrm{n} / \mathrm{a}$ \\
\hline $\begin{array}{l}\text { Ponce \& } \\
\text { Gutiérrez [124] }\end{array}$ & $\begin{array}{l}\text { An indoor predicting } \\
\text { climate conditions approach } \\
\text { using internet-of-things and } \\
\text { artificial hydrocarbon } \\
\text { networks }\end{array}$ & Measurement & $\begin{array}{l}\text { To predict the } \\
\text { temperature of remote } \\
\text { locations using field } \\
\text { sensors and information } \\
\text { from network. }\end{array}$ & $\begin{array}{l}\text { Identifies methods of } \\
\text { incorporating AI in } \\
\text { weather monitoring to } \\
\text { better predict changes. }\end{array}$ & Environment & ML & $\mathrm{NN}$ & $\mathrm{n} / \mathrm{a}$ & $\begin{array}{l}\text { IoT } \\
\text { Artificial } \\
\text { Hydrocarbon } \\
\text { Networks }\end{array}$ \\
\hline Puri et al. [125] & $\begin{array}{l}\text { Hybrid artificial intelligence } \\
\text { and internet of things } \\
\text { model for generation of } \\
\text { renewable resource of } \\
\text { energy }\end{array}$ & IEEE Access & $\begin{array}{l}\text { To develop an IoT based } \\
\text { system to generate } \\
\text { electrical energy from } \\
\text { multiple sensors. }\end{array}$ & $\begin{array}{l}\text { Provides insights into the } \\
\text { use of piezoelectric } \\
\text { sensors to generate } \\
\text { energy from body heat. }\end{array}$ & Environment & ML & $\mathrm{NN}$ & $\mathrm{n} / \mathrm{a}$ & $\begin{array}{l}\text { IoT } \\
\text { Smart Energy }\end{array}$ \\
\hline Quan et al. [146] & $\begin{array}{l}\text { Artificial intelligence-aided } \\
\text { design }\end{array}$ & $\begin{array}{l}\text { Environment and } \\
\text { Planning B }\end{array}$ & $\begin{array}{l}\text { To develop a smart } \\
\text { design framework } \\
\text { which uses AI to assist } \\
\text { urban design } \\
\text { decision-making. }\end{array}$ & $\begin{array}{l}\text { Provides insights into the } \\
\text { use of AI in the design } \\
\text { process }\end{array}$ & Environment & SO & EA & GA & Smart Design \\
\hline $\begin{array}{l}\text { Rahman et al. } \\
\text { [126] }\end{array}$ & $\begin{array}{l}\text { Blockchain and IoT-based } \\
\text { cognitive edge framework } \\
\text { for sharing economy } \\
\text { services in a smart city }\end{array}$ & IEEE Access & $\begin{array}{l}\text { To propose } \\
\text { blockchain-based } \\
\text { infrastructure to } \\
\text { support security- and } \\
\text { privacy-oriented } \\
\text { spatio-temporal smart } \\
\text { contract services. }\end{array}$ & $\begin{array}{l}\text { Identifies benefits of AI in } \\
\text { helping with data } \\
\text { collection, fusing } \\
\text { information from } \\
\text { multiple sources. }\end{array}$ & Economy & ML & NN & DL & $\begin{array}{l}\text { IoT } \\
\text { Blockchain }\end{array}$ \\
\hline
\end{tabular}


Table A1. Cont.

\begin{tabular}{|c|c|c|c|c|c|c|c|c|c|}
\hline Author & Title & Journal & Aim & Relevance & Domain & Paradigm & Application & Method & Technology \\
\hline Ramesh et al. [68] & $\begin{array}{l}\text { Artificial intelligence in } \\
\text { medicine }\end{array}$ & $\begin{array}{l}\text { Annals of The Royal } \\
\text { College of Surgeons } \\
\text { of England }\end{array}$ & $\begin{array}{l}\text { To explore the } \\
\text { proficiency of AI in } \\
\text { medicine. }\end{array}$ & $\begin{array}{l}\text { Provides insights into } \\
\text { how AI can help with the } \\
\text { analysis of complex } \\
\text { medical data. }\end{array}$ & Society & $\begin{array}{l}\text { LB } \\
\text { KB } \\
\text { ML } \\
\text { SO }\end{array}$ & $\begin{array}{l}\text { ES } \\
\text { NN } \\
\text { EA }\end{array}$ & $\begin{array}{l}\text { FS } \\
\text { DL } \\
\text { GA }\end{array}$ & Smart Health \\
\hline $\begin{array}{l}\text { Reaz } \\
{[73]}\end{array}$ & $\begin{array}{l}\text { Artificial intelligence } \\
\text { techniques for advanced } \\
\text { smart home } \\
\text { implementation }\end{array}$ & $\begin{array}{l}\text { Acta Technica } \\
\text { Corvininesis-Bulletin } \\
\text { of Engineering }\end{array}$ & $\begin{array}{l}\text { To develop a platform } \\
\text { which serves as a } \\
\text { reference point for } \\
\text { developing more } \\
\text { cutting-edge smart } \\
\text { home technologies. }\end{array}$ & $\begin{array}{l}\text { Identifies how AI can be } \\
\text { used to provide more } \\
\text { efficient power } \\
\text { consumption }\end{array}$ & Environment & $\begin{array}{l}\text { LB } \\
\text { KB } \\
\text { PM } \\
\text { ML } \\
\text { EI }\end{array}$ & $\begin{array}{l}\text { ES } \\
\text { CV } \\
\text { NN } \\
\text { AS } \\
\text { DAI }\end{array}$ & $\begin{array}{l}\text { FS } \\
\text { AR } \\
\text { MAS }\end{array}$ & Smart Home \\
\hline Rho et al. [72] & $\begin{array}{l}\text { Advanced issues in artificial } \\
\text { intelligence and pattern } \\
\text { recognition for intelligent } \\
\text { surveillance system in } \\
\text { smart home environment }\end{array}$ & $\begin{array}{l}\text { Engineering } \\
\text { Applications of } \\
\text { Artificial } \\
\text { Intelligence }\end{array}$ & $\begin{array}{l}\text { To review topics } \\
\text { strongly related to the } \\
\text { intelligent surveillance } \\
\text { systems in smart homes. }\end{array}$ & $\begin{array}{l}\text { Describes the use of AI in } \\
\text { home surveillance } \\
\text { systems }\end{array}$ & Governance & ML & $\mathrm{n} / \mathrm{a}$ & $\mathrm{n} / \mathrm{a}$ & $\begin{array}{l}\text { Smart } \\
\text { Surveillance } \\
\text { Smart Homes }\end{array}$ \\
\hline Roll \& Wylie [143] & $\begin{array}{l}\text { Evolution and revolution in } \\
\text { artificial intelligence in } \\
\text { education }\end{array}$ & $\begin{array}{l}\text { International } \\
\text { Journal of Artificial } \\
\text { Intelligence in } \\
\text { Education }\end{array}$ & $\begin{array}{l}\text { To review papers to } \\
\text { identify the focus and } \\
\text { typical scenarios that } \\
\text { occupy the field of AI } \\
\text { and education. }\end{array}$ & $\begin{array}{l}\text { Describes how AI will } \\
\text { impact the job market and } \\
\text { create effective } \\
\text { educational system. }\end{array}$ & Society & $\begin{array}{l}\text { LB } \\
\text { KB }\end{array}$ & ES & $\mathrm{n} / \mathrm{a}$ & $\begin{array}{l}\text { Smart } \\
\text { Education }\end{array}$ \\
\hline $\begin{array}{l}\text { Ruohomaa et al. } \\
\text { [127] }\end{array}$ & $\begin{array}{l}\text { Towards smart city concept } \\
\text { in small cities }\end{array}$ & $\begin{array}{l}\text { Technology } \\
\text { Innovation } \\
\text { Management } \\
\text { Review }\end{array}$ & $\begin{array}{l}\text { To present the practical } \\
\text { viewpoints, cases and } \\
\text { experiences relating to } \\
\text { the planning of smart } \\
\text { cities. }\end{array}$ & $\begin{array}{l}\text { Identifies shared learning } \\
\text { and cooperation as } \\
\text { important factors in } \\
\text { increasing innovation and } \\
\text { growth in smart cities. }\end{array}$ & Economy & ML & $\mathrm{n} / \mathrm{a}$ & $\mathrm{n} / \mathrm{a}$ & IoT \\
\hline $\begin{array}{l}\text { Sgantzos \& Grigg } \\
\text { [128] }\end{array}$ & $\begin{array}{l}\text { Artificial intelligence } \\
\text { implementations on the } \\
\text { blockchain }\end{array}$ & Future Internet & $\begin{array}{l}\text { To reveal the potential } \\
\text { combined applications } \\
\text { of } \mathrm{AI} \text { and blockchain. }\end{array}$ & $\begin{array}{l}\text { Describes the potential for } \\
\text { AI to be an independent } \\
\text { source of knowledge and } \\
\text { innovation. }\end{array}$ & Economy & $\begin{array}{l}\text { ML } \\
\text { EI } \\
\text { SO }\end{array}$ & $\begin{array}{l}\text { NN } \\
\text { DAI } \\
\text { EA }\end{array}$ & $\begin{array}{l}\text { MAS } \\
\text { GA }\end{array}$ & $\begin{array}{l}\text { IoT } \\
\text { Blockchain }\end{array}$ \\
\hline Shi et al. [129] & $\begin{array}{l}\text { Smart textile-integrated } \\
\text { microelectronic systems for } \\
\text { wearable applications }\end{array}$ & $\begin{array}{l}\text { Advanced } \\
\text { Materials }\end{array}$ & $\begin{array}{l}\text { To provide an overview } \\
\text { of the progress of the } \\
\text { smart textile field. }\end{array}$ & $\begin{array}{l}\text { Describes the use of smart } \\
\text { textiles for health care } \\
\text { monitoring. }\end{array}$ & Society & ML & NN & $\mathrm{n} / \mathrm{a}$ & Smart Textiles \\
\hline $\begin{array}{l}\text { Soomro et al. } \\
\text { [130] }\end{array}$ & Smart city big data analytics & $\begin{array}{l}\text { Wiley } \\
\text { Interdisciplinary } \\
\text { Reviews: Data } \\
\text { Mining and } \\
\text { Knowledge } \\
\text { Discovery }\end{array}$ & $\begin{array}{l}\text { To present classification } \\
\text { model that studies four } \\
\text { aspects of research in } \\
\text { the big data analytics } \\
\text { domain. }\end{array}$ & $\begin{array}{l}\text { Provides insights into the } \\
\text { potential for machine } \\
\text { learning to complete } \\
\text { complex statistical } \\
\text { analysis and make more } \\
\text { informed decisions. }\end{array}$ & Economy & $\begin{array}{l}\text { ML } \\
\text { SO }\end{array}$ & $\begin{array}{l}\mathrm{NN} \\
\mathrm{EA}\end{array}$ & GA & $\mathrm{n} / \mathrm{a}$ \\
\hline
\end{tabular}


Table A1. Cont.

\begin{tabular}{|c|c|c|c|c|c|c|c|c|c|}
\hline Author & Title & Journal & Aim & Relevance & Domain & Paradigm & Application & Method & Technology \\
\hline Stefanelli [139] & $\begin{array}{l}\text { The socio-organizational } \\
\text { age of artificial intelligence } \\
\text { in medicine }\end{array}$ & $\begin{array}{l}\text { Artificial } \\
\text { Intelligence in } \\
\text { Medicine }\end{array}$ & $\begin{array}{l}\text { To explore the great } \\
\text { challenges for AI in } \\
\text { medicine. }\end{array}$ & $\begin{array}{l}\text { Identifies AI as an } \\
\text { effective way to manage } \\
\text { medical knowledge, and } \\
\text { increase resources for } \\
\text { patient care. }\end{array}$ & Society & KB & $\mathrm{n} / \mathrm{a}$ & $\mathrm{n} / \mathrm{a}$ & Smart Health \\
\hline $\begin{array}{l}\text { Streitz } \\
\text { [131] }\end{array}$ & $\begin{array}{l}\text { Beyond 'smart-only' cities: } \\
\text { redefining the } \\
\text { 'smart-everything' } \\
\text { paradigm }\end{array}$ & $\begin{array}{l}\text { Journal of Ambient } \\
\text { Intelligence and } \\
\text { Humanized } \\
\text { Computing }\end{array}$ & $\begin{array}{l}\text { To present the various } \\
\text { manifestations of the } \\
\text { smart everything } \\
\text { paradigm. }\end{array}$ & $\begin{array}{l}\text { Identifies the need for } \\
\text { privacy-by-design to } \\
\text { empower people and } \\
\text { enforce a citizen centric } \\
\text { approach to data } \\
\text { collection. }\end{array}$ & Governance & ML & $\mathrm{NN}$ & DL & IoT \\
\hline Syifa et al. [132] & $\begin{array}{l}\text { An artificial intelligence } \\
\text { application for } \\
\text { post-earthquake damage } \\
\text { mapping in Palu, Central } \\
\text { Sulawesi, Indonesia }\end{array}$ & Sensors & $\begin{array}{l}\text { To develop a } \\
\text { classification of pre- and } \\
\text { post-earthquake satellite } \\
\text { images using ANN and } \\
\text { support vector machine } \\
\text { classifiers. }\end{array}$ & $\begin{array}{l}\text { Provides insights into the } \\
\text { use of AI subsets artificial } \\
\text { neural networks and } \\
\text { support vector machine } \\
\text { classifiers to identify areas } \\
\text { affected by earthquakes }\end{array}$ & Governance & ML & $\mathrm{NN}$ & $\mathrm{n} / \mathrm{a}$ & $\mathrm{n} / \mathrm{a}$ \\
\hline $\begin{array}{l}\text { Wan \& Hwang } \\
\text { [97] }\end{array}$ & $\begin{array}{l}\text { Value-based deep } \\
\text { reinforcement learning for } \\
\text { adaptive isolated } \\
\text { intersection signal control }\end{array}$ & $\begin{array}{l}\text { IET Intelligent } \\
\text { Transport Systems }\end{array}$ & $\begin{array}{l}\text { To identify the use of } \\
\text { reinforcement learning } \\
\text { in signal controls. }\end{array}$ & $\begin{array}{l}\text { Describes using traffic } \\
\text { signal control methods for } \\
\text { transport system } \\
\text { optimization. }\end{array}$ & Environment & $\begin{array}{l}\mathrm{PM} \\
\mathrm{ML}\end{array}$ & $\begin{array}{l}\mathrm{PP} \\
\mathrm{NN}\end{array}$ & DL & $\begin{array}{l}\text { Smart } \\
\text { Transport }\end{array}$ \\
\hline $\begin{array}{l}\text { Wang \& } \\
\text { Srinivasan [81] }\end{array}$ & $\begin{array}{l}\text { A review of artificial } \\
\text { intelligence-based building } \\
\text { energy use prediction }\end{array}$ & $\begin{array}{l}\text { Renewable and } \\
\text { Sustainable Energy } \\
\text { Reviews }\end{array}$ & $\begin{array}{l}\text { To better understand of } \\
\text { the use of ensemble } \\
\text { models for predicting } \\
\text { building energy use. }\end{array}$ & $\begin{array}{l}\text { Discusses the use of AI in } \\
\text { building use energy } \\
\text { predictions. }\end{array}$ & Environment & $\begin{array}{l}\mathrm{PM} \\
\mathrm{ML}\end{array}$ & $\begin{array}{l}\mathrm{PP} \\
\mathrm{NN}\end{array}$ & $\mathrm{n} / \mathrm{a}$ & $\mathrm{n} / \mathrm{a}$ \\
\hline Wang et al. [133] & $\begin{array}{l}\text { Exploring the application of } \\
\text { artificial intelligence } \\
\text { technology for } \\
\text { identification of water } \\
\text { pollution characteristics } \\
\text { and tracing the source of } \\
\text { water quality pollutants }\end{array}$ & $\begin{array}{l}\text { Science of The Total } \\
\text { Environment }\end{array}$ & $\begin{array}{l}\text { To develop an AI } \\
\text { scheme for identifying } \\
\text { spatiotemporal water } \\
\text { quality distributions } \\
\text { and the relationships } \\
\text { between water quality } \\
\text { indicators and } \\
\text { industrial point sources } \\
\text { of pollutants. }\end{array}$ & $\begin{array}{l}\text { Identifies the potential for } \\
\text { AI to monitor water } \\
\text { pollutant levels and } \\
\text { changes }\end{array}$ & Environment & ML & $\mathrm{NN}$ & DL & $\begin{array}{l}\text { Smart } \\
\text { Environment }\end{array}$ \\
\hline Wei et al. [134] & $\begin{array}{l}\text { Conventional models and } \\
\text { artificial intelligence-based } \\
\text { models for energy } \\
\text { consumption forecasting: a } \\
\text { review }\end{array}$ & $\begin{array}{l}\text { Journal of } \\
\text { Petroleum Science } \\
\text { and Engineering }\end{array}$ & $\begin{array}{l}\text { To review conventional } \\
\text { models and AI based } \\
\text { models in energy } \\
\text { consumption } \\
\text { forecasting. }\end{array}$ & $\begin{array}{l}\text { Describes how Ai can be } \\
\text { used in energy forecasting } \\
\text { to assist with identifying } \\
\text { inefficiencies in energy } \\
\text { consumption and } \\
\text { pollution prevention. }\end{array}$ & Environment & $\begin{array}{l}\text { PM } \\
\text { ML } \\
\text { EI } \\
\text { SO }\end{array}$ & $\begin{array}{l}\text { DN } \\
\text { NN } \\
\text { DAI } \\
\text { EA }\end{array}$ & $\begin{array}{l}\text { BN } \\
\text { DL } \\
\text { SI } \\
\text { GA }\end{array}$ & Smart Energy \\
\hline Wogu et al. [135] & $\begin{array}{l}\text { Artificial intelligence, smart } \\
\text { classrooms and online } \\
\text { education in the 21st } \\
\text { century }\end{array}$ & $\begin{array}{l}\text { Journal of Cases on } \\
\text { Information } \\
\text { Technology }\end{array}$ & $\begin{array}{l}\text { To investigate impact of } \\
\text { AI innovations in the } \\
\text { education sector and on } \\
\text { human development }\end{array}$ & $\begin{array}{l}\text { Describes the potential } \\
\text { changes AI will bring to } \\
\text { the education sector. }\end{array}$ & Society & ML & $\mathrm{n} / \mathrm{a}$ & $\mathrm{n} / \mathrm{a}$ & $\begin{array}{l}\text { Smart } \\
\text { Education }\end{array}$ \\
\hline
\end{tabular}


Table A1. Cont.

\begin{tabular}{|c|c|c|c|c|c|c|c|c|c|}
\hline Author & Title & Journal & Aim & Relevance & Domain & Paradigm & Application & Method & Technology \\
\hline Wu \& Silva [26] & $\begin{array}{l}\text { Artificial intelligence } \\
\text { solutions for urban land } \\
\text { dynamics }\end{array}$ & $\begin{array}{l}\text { Journal of Planning } \\
\text { Literature }\end{array}$ & $\begin{array}{l}\text { To increase } \\
\text { understanding of how } \\
\text { AI approaches urban } \\
\text { and land dynamics } \\
\text { modelling processes. }\end{array}$ & $\begin{array}{l}\text { Discusses the use of AI in } \\
\text { identifying the dynamics } \\
\text { of urban land use. }\end{array}$ & Environment & $\begin{array}{l}\text { KB } \\
\text { ML } \\
\text { EI } \\
\text { SO }\end{array}$ & $\begin{array}{l}\text { ES } \\
\text { NN } \\
\text { DAI } \\
\text { EA }\end{array}$ & $\begin{array}{l}\text { FS } \\
\text { ABM } \\
\text { SI } \\
\text { GA }\end{array}$ & $\mathrm{n} / \mathrm{a}$ \\
\hline Yu et al. [150] & $\begin{array}{l}\text { Decentralized big data } \\
\text { auditing for smart city } \\
\text { environments leveraging } \\
\text { blockchain technology }\end{array}$ & IEEE Access & $\begin{array}{l}\text { To design a blockchain } \\
\text { instantiation and } \\
\text { conduct a comparison } \\
\text { between the existing } \\
\text { and proposed schemes. }\end{array}$ & $\begin{array}{l}\text { Identifies the potential for } \\
\text { AI to processing and } \\
\text { analyzing large amounts } \\
\text { of data }\end{array}$ & Economy & $\mathrm{n} / \mathrm{a}$ & $\mathrm{n} / \mathrm{a}$ & $\mathrm{n} / \mathrm{a}$ & Blockchain \\
\hline Yun et al. [76] & $\begin{array}{l}\text { Not deep learning but } \\
\text { autonomous learning of } \\
\text { open innovation for } \\
\text { sustainable artificial } \\
\text { intelligence }\end{array}$ & Sustainability & $\begin{array}{l}\text { To build an interaction } \\
\text { model between direct } \\
\text { and autonomous } \\
\text { learning. }\end{array}$ & $\begin{array}{l}\text { Investigates the potential } \\
\text { for AI to develop } \\
\text { autonomous learning } \\
\text { capabilities. }\end{array}$ & Economy & $\begin{array}{l}\text { ML } \\
\text { EI }\end{array}$ & $\begin{array}{l}\text { AS } \\
\text { DAI }\end{array}$ & SI & $\mathrm{n} / \mathrm{a}$ \\
\hline Zou et al. [157] & $\begin{array}{l}\text { Exploring urban population } \\
\text { forecasting and spatial } \\
\text { distribution modeling with } \\
\text { artificial intelligence } \\
\text { technology }\end{array}$ & $\begin{array}{l}\text { Computer } \\
\text { Modeling in } \\
\text { Engineering \& } \\
\text { Sciences }\end{array}$ & $\begin{array}{l}\text { To improve the } \\
\text { precision of small area } \\
\text { population forecasting. }\end{array}$ & $\begin{array}{l}\text { Describes the use of AI in } \\
\text { population forecasting }\end{array}$ & Environment & $\mathrm{n} / \mathrm{a}$ & $\mathrm{n} / \mathrm{a}$ & $\mathrm{n} / \mathrm{a}$ & $\mathrm{n} / \mathrm{a}$ \\
\hline
\end{tabular}

Notes: $\mathrm{n} / \mathrm{a}=$ not available as not identified in the article. AI Paradigms: Logic-based (LB), Knowledge-based (KB), Probabilistic Methods (PM), Machine Learning (ML), Embodied Intelligence (EI), and Search and Optimization (SO). AI Applications: Autonomous Systems (AS), Computer Vision (CV), Distributed Artificial Intelligence (DAI), Decision Networks (DN),

Evolutionary Algorithms (EA), Expert Systems (ES), Inductive Logic Programming (ILP), Natural Language Processing (NLP), Neural Networks (NN), and Probabilistic Programming (PP). AI Methods: Agent-Based Modelling (ABM), Activities Recognition (AR), Bayesian Networks (BN), Bayesian Program Synthesis (BPS), Deep Learning (DL), Fuzzy Systems (FS), Genetic Algorithms (GA), Image Recognition (IR), Multi-Agent Systems (MAS)., Machine Vision (MV), Natural Language Generation (NLG), Natural Language Understanding (NLU), and Swarm Intelligence (SI) 


\section{References}

1. Oreskes, N. The scientific consensus on climate change. Science 2004, 306, 1686. [CrossRef]

2. Cook, J.; Nuccitelli, D.; Green, S.A.; Richardson, M.; Winkler, B.; Painting, R.; Skuce, A. Quantifying the consensus on anthropogenic global warming in the scientific literature. Environ. Res. Lett. 2013, 8, 024024. [CrossRef]

3. Yigitcanlar, T.; Foth, M.; Kamruzzaman, M. Towards post-anthropocentric cities: Reconceptualizing smart cities to evade urban ecocide. J. Urban Technol. 2019, 26, 147-152. [CrossRef]

4. Kankanamge, N.; Yigitcanlar, T.; Goonetilleke, A.; Kamruzzaman, M. Determining disaster severity through social media analysis: Testing the methodology with South East Queensland Flood tweets. Int. J. Disaster Risk Reduct. 2020, 42, 101360. [CrossRef]

5. Sotto, D.; Philippi, A.; Yigitcanlar, T.; Kamruzzaman, M. Aligning urban policy with climate action in the global South: Are Brazilian cities considering climate emergency in local planning practice? Energies 2019, 12, 3418. [CrossRef]

6. Yu, P.; Xu, R.; Abramson, M.J.; Li, S.; Guo, Y. Bushfires in Australia: A serious health emergency under climate change. Lancet Planet. Health 2020, 4, 7-8. [CrossRef]

7. Zhenmin, L.; Espinosa, P. Tackling climate change to accelerate sustainable development. Nat. Clim. Chang. 2019, 9, 494-496. [CrossRef]

8. Kinniburgh, C. Can extinction rebellion survive? Dissent 2020, 67, 125-133. [CrossRef]

9. Tomitsch, M.; Haeusler, M.H. Infostructures: Towards a complementary approach for solving urban challenges through digital technologies. J. Urban Technol. 2015, 22, 37-53. [CrossRef]

10. Yigitcanlar, T.; Kamruzzaman, M. Does smart city policy lead to sustainability of cities? Land Use Policy 2018, 73, 49-58. [CrossRef]

11. Yigitcanlar, T.; Inkinen, T. Geographies of Disruption: Place Making for Innovation in the Age of Knowledge Economy; Springer International Publishing: Cham, Switzerland, 2019.

12. Yigitcanlar, T.; Kamruzzaman, M. Smart cities and mobility: Does the smartness of Australian cities lead to sustainable commuting patterns? J. Urban Technol. 2019, 26, 21-46. [CrossRef]

13. Arbolino, R.; De Simone, L.; Carlucci, F.; Yigitcanlar, T.; Ioppolo, G. Towards a sustainable industrial ecology: Implementation of a novel approach in the performance evaluation of Italian regions. J. Clean. Prod. 2018, 178, 220-236. [CrossRef]

14. Yigitcanlar, T.; Kamruzzaman, M.D.; Buys, L.; Perveen, S. Smart Cities of the Sunshine State: Status of Queensland's Local Government Areas. Available online: https://eprints.qut.edu.au/118349/ (accessed on 10 February 2020).

15. Desouza, K.C.; Swindell, D.; Smith, K.L.; Sutherland, A.; Fedorschak, K.; Coronel, C. Local government 2035: Strategic trends and implications of new technologies. Issues Technol. Innov. 2015, 27, 27.

16. Kyriazopoulou, C. Smart city technologies and architectures: A literature review. In Proceedings of the 2015 International Conference on Smart Cities and Green ICT Systems, Lisbon, Portugal, 20-22 May 2015; pp. 1-12.

17. Ab-Rahman, A.; Hamid, U.Z.; Chin, T.A. Emerging technologies with disruptive effects: A review. Perintis e-J. 2017, 7, 111-128.

18. Gatzweiler, F.W. Advancing urban health and wellbeing through collective and artificial intelligence: A system approach 3.0. In Urban Health and Wellbeing Programme; Springer: Singapore, 2020; pp. 33-38.

19. King, B.A.; Hammond, T.; Harrington, J. Disruptive technology: Economic consequences of artificial intelligence and the robotics revolution. J. Strateg. Innov. Sustain. 2017, 12, 53-67.

20. Tegmark, M. Life 3.0: Being Human in the Age of Artificial Intelligence; Knopf: New York, NY, USA, 2017.

21. Yigitcanlar, T. Technology and the City: Systems, Applications and Implications; Routledge: Abingdon upon Thames, UK, 2016.

22. Batty, M. Artificial intelligence and smart cities. Environ. Plan. Urban Anal. City Sci. 2018, 45, 3-6. [CrossRef]

23. Schalkoff, R.J. Artificial Intelligence: An Engineering Approach; McGraw-Hill: New York, NY, USA, 1990.

24. Pannu, A. Artificial intelligence and its application in different areas. Artif. Intell. 2015, 4, 79-84.

25. Corea, F. AI Knowledge Map: How to Classify AI Technologies. Available online: https://www.forbes. com/sites/cognitiveworld/2018/08/22/ai-knowledge-map-how-to-classify-ai-technologies/\#5e99db627773 (accessed on 18 January 2020). 
26. Wu, N.; Silva, E.A. Artificial intelligence solutions for urban land dynamics: A review. J. Plan. Lit. 2010, 24, 246-265.

27. Jiafeng, Z.; Tian, L.; Lin, Z. Artificial intelligence approach to creative data manipulation for optimisation of livelihood oriented urban planning and management. Int. J. Perform. Eng. 2019, 15, 602-610.

28. Wirtz, B.W.; Weyerer, J.C.; Geyer, C. Artificial intelligence and the public sector: Applications and challenges. Int. J. Public Adm. 2019, 42, 596-615. [CrossRef]

29. Mendling, J.; Decker, G.; Hull, R.; Reijers, H.A.; Weber, I. How do machine learning, robotic process automation, and blockchains affect the human factor in business process management? Commun. Assoc. Inf. Syst. 2018, 43, 297-320. [CrossRef]

30. Faisal, A.; Yigitcanlar, T.; Kamruzzaman, M.; Currie, G. Understanding autonomous vehicles: A systematic literature review on capability, impact, planning and policy. J. Transp. Land Use 2019, 12, 45-72. [CrossRef]

31. Japan Times. ANA Starts Testing Semi-Autonomous Bus at Haneda Airport for Passengers and Staff. Available online: https://www.japantimes.co.jp/news/2020/01/22/national/ana-starts-testing-autonomousbus-operation-haneda-airport/\#.XjN_rGgzZnI (accessed on 31 January 2020).

32. Yigitcanlar, T.; Wilson, M.; Kamruzzaman, M. Disruptive impacts of automated driving systems on the built environment and land use: An urban planner's perspective. J. Open Innov. Technol. Mark. Complex. 2019, 5, 24. [CrossRef]

33. Yigitcanlar, T.; Kamruzzaman, M.; Foth, M.; Sabatini-Marques, J.; da Costa, E.; Ioppolo, G. Can cities become smart without being sustainable? A systematic review of the literature. Sustain. Cities Soc. 2019, 45, 348-365. [CrossRef]

34. Houston Chronicle. Robot Police Coming to Houston Transit Center, Rail Platform, Park and Ride Lot. Available online: https://www.houstonchronicle.com/news/transportation/article/Robot-police-coming-toHouston-transit-center-14999004.php (accessed on 23 January 2020).

35. Washington Post. One Solution for Keeping Traffic Stops from Turning Violent: A Robot that Separates Police Officers from Drivers. Available online: https://www.washingtonpost.com/technology/2019/05/14/ one-solution-keeping-traffic-stops-turning-violent-robot-that-separates-police-officers-drivers (accessed on 25 January 2020).

36. Swindell, D.; Desouza, K.C.; Hudgens, R. Dubai Offers Lessons for Using Artificial Intelligence in Local Government; Brookings: Washington, DC, USA, 2018.

37. Chang, C.W.; Lee, H.W.; Liu, C.H. A review of artificial intelligence algorithms used for smart machine tools. Inventions 2018, 3, 41. [CrossRef]

38. Desouza, K.C.; Smith, K.L. Big Data and Planning; American Planning Association: Washington, DC, USA, 2016; Volume 585, pp. 2-102.

39. Desouza, K.C. Delivering Artificial Intelligence in Government: Challenges and Opportunities; IBM Center for the Business of Government: Washington, DC, USA, 2018.

40. Thakuriah, P.V.; Tilahun, N.Y.; Zellner, M. Seeing Cities through Big Data; Springer: Singapore, 2017; pp. 1-9.

41. Sadilek, A.; Kautz, H.; DiPrete, L.; Labus, B.; Portman, E.; Teitel, J.; Silenzio, V. Deploying nEmesis: Preventing foodborne illness by data mining social media. In Proceedings of the 13th IAAI Conference on AI, Seattle, WA, USA; 2016; pp. 3982-3989.

42. BBC. Durham Police AI to Help with Custody Decisions. Available online: http://www.bbc.com/news/ technology-39857645 (accessed on 31 January 2020).

43. Accenture. Accenture Helps Seattle Police Department Implement Data Analytics Platform. Available online: https://newsroom.accenture.com/news/accenture-helps-seattle-police-department-implement-dataanalytics-platform.htm (accessed on 1 February 2020).

44. Fastcompany. San Diego's Massive, 7-Year Experiment with Facial Recognition Technology Appears to be a Flop. Available online: https://www.fastcompany.com/90440198/san-diegos-massive-7-year-experimentwith-facial-recognition-technology-appears-to-be-a-flop (accessed on 17 February 2020).

45. Madaio, M.; Haimson, O.L.; Zhang, W.; Cheng, X.; Hinds-Aldrich, M.; Dilkina, B.; Chau, D.H.P. Identifying and Prioritizing Fire Inspections: A Case Study of Predicting Fire Risk in Atlanta; Bloomberg: New York, NY, USA, 2015.

46. Yigitcanlar, T.; Han, H.; Kamruzzaman, M. Approaches, advances, and applications in the sustainable development of smart cities: A commentary from the guest editors. Energies 2019, 12, 4554. [CrossRef] 
47. New York Times. Another Hacked Florida City Pays a Ransom, This Time for $\$ 460,000$. Available online: https:/www.nytimes.com/2019/06/27/us/lake-city-florida-ransom-cyberattack.html (accessed on 1 February 2020).

48. MIT News. System Predicts 85 Percent of Cyber-Attacks Using Input from Human Experts. Available online: http://news.mit.edu/2016/ai-system-predicts-85-percent-cyber-attacks-using-input-human-experts0418 (accessed on 30 January 2020).

49. Smith, S.F.; Barlow, G.J.; Xie, X.F.; Rubinstein, Z.B. Smart urban signal networks: Initial application of the SURTRAC adaptive traffic signal control system. In Proceedings of the 23rd International Conference on Automated Planning and Scheduling, Rome, Italy, 10-14 June 2013; pp. 434-442.

50. Curbed. Criticism Mounts over Detroit Police Department's Facial Recognition Software. Available online: https://detroit.curbed.com/2019/7/8/20687045/project-green-light-detroit-facial-recognitiontechnology (accessed on 1 February 2020).

51. The Guardian. What is Fake News? How to Spot It and What You Can Do to Stop It. Available online: https: //www.theguardian.com/media/2016/dec/18/what-is-fake-news-pizzagate (accessed on 1 February 2020).

52. Washington Post. N.C. Man Told Police He Went to D.C. Pizzeria with Gun to Investigate Conspiracy Theory. Available online: https://www.washingtonpost.com/news/local/wp/2016/12/04/d-c-police-respond-to-reportof-a-man-with-a-gun-at-comet-ping-pong-restaurant (accessed on 1 February 2020).

53. Azcentral. A Slashed Tire, A Pointed Gun, Bullies on the Road: Why do Waymo Self-Driving Vans Get So Much Hate? Available online: https://www.azcentral.com/story/money/business/tech/2018/12/11/waymoself-driving-vehicles-face-harassment-road-rage-phoenix-area/2198220002 (accessed on 1 February 2020).

54. Selby, J.D.; Desouza, K.C. Fragile cities in the developed world: A conceptual framework. Cities 2019, 91, 180-192. [CrossRef]

55. Desouza, K.C.; Selby, J.D. How Technological Progress Can Cause Urban Fragility; Brookings Institute: Washington, DC, USA, 2019.

56. NHTSA. The Automatic Emergency Braking (AEB) or Autopilot Systems May Not Function as Designed, Increasing the Risk of a Crash. Available online: https://static.nhtsa.gov/odi/inv/2016/INCLA-PE16007-7876. pdf (accessed on 1 February 2020).

57. CNN. Chrysler Recalls 1.4 Million Hackable Cars. Available online: http://money.cnn.com/2015/07/24/ technology/chrysler-hack-recall/index.html (accessed on 1 February 2020).

58. CNN. Chryslers Can be Hacked over the Internet. Available online: http://money.cnn.com/2015/07/21/ technology/chrysler-hack/index.html (accessed on 1 February 2020).

59. Slate. Autonomous Vehicles will Cost Local Governments Big Bucks. Available online: http://www.slate. com/blogs/future_tense/2015/06/16/autonomous_vehicles_will_cost_local_governments_big_bucks.html (accessed on 1 February 2020).

60. Az Central. Self-Driving Cars may Cost Cities. Available online: http://www.azcentral.com/story/news/ arizona/politics/2015/07/01/self-driving-cars-cityrevenue/29598929 (accessed on 1 February 2020).

61. Yigitcanlar, T.; Kamruzzaman, M.; Buys, L.; Ioppolo, G.; Sabatini-Marques, J.; da Costa, E.M.; Yun, J.J. Understanding 'smart cities': Intertwining development drivers with desired outcomes in a multidimensional framework. Cities 2018, 81, 145-160. [CrossRef]

62. Yigitcanlar, T.; Han, H.; Kamruzzaman, M.; Ioppolo, G.; Sabatini-Marques, J. The making of smart cities: Are Songdo, Masdar, Amsterdam, San Francisco and Brisbane the best we could build? Land Use Policy 2019, 88, 104187. [CrossRef]

63. Feng, S.; Xu, L. An intelligent decision support system for fuzzy comprehensive evaluation of urban development. Expert Syst. Appl. 1999, 16, 21-32. [CrossRef]

64. Shrivastava, R.; Mahajan, P. Artificial intelligence research in India: A scientometric analysis. Sci. Technol. Libr. 2016, 35, 136-151. [CrossRef]

65. Makarynskyy, O.; Makarynska, D.; Kuhn, M.; Featherstone, W.E. Predicting sea level variations with artificial neural networks at Hillarys Boat Harbour, Western Australia. Estuar. Coast. Shelf Sci. 2004, 61, 351-360. [CrossRef]

66. Aziz, K.; Haque, M.M.; Rahman, A.; Shamseldin, A.Y.; Shoaib, M. Flood estimation in ungauged catchments: Application of artificial intelligence-based methods for Eastern Australia. Stoch. Environ. Res. Risk Assess. 2017, 31, 1499-1514. [CrossRef] 
67. Hanson, C.W.; Marshall, B.E. Artificial intelligence applications in the intensive care unit. Crit. Care Med. 2001, 29, 427-435. [CrossRef] [PubMed]

68. Ramesh, A.N.; Kambhampati, C.; Monson, J.R.; Drew, P.J. Artificial intelligence in medicine. Ann. R. Coll. Surg. Engl. 2004, 86, 334-338. [CrossRef] [PubMed]

69. Chau, K.W. A review on integration of artificial intelligence into water quality modelling. Mar. Pollut. Bull. 2006, 52, 726-733. [CrossRef]

70. Patel, V.L.; Shortliffe, E.H.; Stefanelli, M.; Szolovits, P.; Berthold, M.R.; Bellazzi, R.; Abu-Hanna, A. The coming of age of artificial intelligence in medicine. Artif. Intell. Med. 2009, 46, 5-17. [CrossRef]

71. Drigas, A.S.; Ioannidou, R.E. Artificial intelligence in special education: A decade review. Int. J. Eng. Educ. 2012, 28, 1366.

72. Rho, S.; Min, G.; Chen, W. Advanced issues in artificial intelligence and pattern recognition for intelligent surveillance system in smart home environment. Eng. Appl. Artif. Intell. 2012, 25, 1299-1300. [CrossRef]

73. Reaz, M.B. Artificial intelligence techniques for advanced smart home implementation. Acta Tech. Corvininesis Bull. Eng. 2013, 6, 51-57.

74. Chmiel, W.; Dańda, J.; Dziech, A.; Ernst, S.; Kadłuczka, P.; Mikrut, Z.; Pawlik, P.; Szwed, P.; Wojnicki, I. INSIGMA: An intelligent transportation system for urban mobility enhancement. Multimed. Tools Appl. 2016, 75, 10529-10560. [CrossRef]

75. De Paz, J.F.; Bajo, J.; Rodríguez, S.; Villarrubia, G.; Corchado, J.M. Intelligent system for lighting control in smart cities. Inf. Sci. 2016, 372, 241-255. [CrossRef]

76. Yun, J.; Lee, D.; Ahn, H.; Park, K.; Yigitcanlar, T. Not deep learning but autonomous learning of open innovation for sustainable artificial intelligence. Sustainability 2016, 8, 797. [CrossRef]

77. Alam, F.; Mehmood, R.; Katib, I.; Albogami, N.N.; Albeshri, A. Data fusion and IoT for smart ubiquitous environments: A survey. IEEE Access 2017, 5, 9533-9554. [CrossRef]

78. Bose, B.K. Artificial intelligence techniques in smart grid and renewable energy systems: Some example applications. Proc. IEEE 2017, 105, 2262-2273. [CrossRef]

79. Garlík, B. The application of artificial intelligence in the process of optimizing energy consumption in intelligent areas. Neural Netw. World 2017, 27, 415-446. [CrossRef]

80. Jha, S.K.; Bilalovic, J.; Jha, A.; Patel, N.; Zhang, H. Renewable energy: Present research and future scope of artificial intelligence. Renew. Sustain. Energy Rev. 2017, 77, 297-317. [CrossRef]

81. Wang, Z.; Srinivasan, R.S. A review of artificial intelligence-based building energy use prediction: Contrasting the capabilities of single and ensemble prediction models. Renew. Sustain. Energy Rev. 2017, 75, 796-808. [CrossRef]

82. Bajaj, R.; Sharma, V. Smart education with artificial intelligence-based determination of learning styles. Procedia Comput. Sci. 2018, 132, 834-842. [CrossRef]

83. Braun, T.; Fung, B.C.; Iqbal, F.; Shah, B. Security and privacy challenges in smart cities. Sustain. Cities Soc. 2018, 39, 499-507. [CrossRef]

84. Casares, A.P. The brain of the future and the viability of democratic governance: The role of artificial intelligence, cognitive machines, and viable systems. Futures 2018, 103, 5-16. [CrossRef]

85. Chassignol, M.; Khoroshavin, A.; Klimova, A.; Bilyatdinova, A. Artificial intelligence trends in education: A narrative overview. Procedia Comput. Sci. 2018, 136, 16-24. [CrossRef]

86. Chui, K.; Lytras, M.; Visvizi, A. Energy sustainability in smart cities: Artificial intelligence, smart monitoring, and optimization of energy consumption. Energies 2018, 11, 2869. [CrossRef]

87. Dobrescu, E.M.; Dobrescu, E.M. Artificial intelligence (AI): The technology that shapes the world. Glob. Econ. Obs. 2018, 6, 71-81.

88. Edwards, C.; Edwards, A.; Spence, P.R.; Lin, X. I, teacher: Using artificial intelligence (AI) and social robots in communication and instruction. Commun. Educ. 2018, 67, 473-480. [CrossRef]

89. Guo, J.; Li, B. The application of medical artificial intelligence technology in rural areas of developing countries. Health Equity 2018, 2, 174-181. [CrossRef]

90. Guo, K.; Lu, Y.; Gao, H.; Cao, R. Artificial intelligence-based semantic internet of things in a user-centric smart city. Sensors 2018, 18, 1341. [CrossRef]

91. Håkansson, A. Ipsum: An approach to smart volatile ICT-infrastructures for smart cities and communities. Procedia Comput. Sci. 2018, 126, 2107-2116. [CrossRef] 
92. Kopytko, V.; Shevchuk, L.; Yankovska, L.; Semchuk, Z.; Strilchuk, R. Smart home and artificial intelligence as environment for the implementation of new technologies. Traektoriâ Nauk. Path Sci. 2018, 4, 2007-2012. [CrossRef]

93. Liu, G.; Liu, S.; Muhammad, K.; Sangaiah, A.K.; Doctor, F. Object tracking in vary lighting conditions for fog based intelligent surveillance of public spaces. IEEE Access 2018, 6, 29283-29296. [CrossRef]

94. Lukowicz, P.; Slusallek, P. How to avoid an AI interaction singularity. Interactions 2018, 25, 72-78. [CrossRef]

95. Martins, J.S. Towards smart city innovation under the perspective of software-defined networking, artificial intelligence and big data. Rev. Tecnol. Inf. Comun. 2018, 8, 1-8.

96. Nápoles, V.M.; Rodríguez, M.D.; Páez, D.G.; Penelas, J.L.; García-Ochoa, A.G.; Pérez, A.L. MUSA-I: Towards new social tools for advanced multi-modal transportation in smart cities. Multidiscip. Digit. Publ. Inst. Proc. 2018, 2, 1215. [CrossRef]

97. Wan, C.H.; Hwang, M.C. Value-based deep reinforcement learning for adaptive isolated intersection signal control. IET Intell. Transp. Syst. 2018, 12, 1005-1010. [CrossRef]

98. Abduljabbar, R.; Dia, H.; Liyanage, S.; Bagloee, S. Applications of artificial intelligence in transport: An overview. Sustainability 2019, 11, 189. [CrossRef]

99. Ajerla, D.; Mahfuz, S.; Zulkernine, F. A real-time patient monitoring framework for fall detection. Wirel. Commun. Mob. Comput. 2019, 2019. [CrossRef]

100. Allam, Z.; Dhunny, Z.A. On big data, artificial intelligence and smart cities. Cities 2019, 89, 80-91. [CrossRef]

101. Alsamhi, S.H.; Ma, O.; Ansari, M.S.; Almalki, F.A. Survey on collaborative smart drones and internet of things for improving smartness of smart cities. IEEE Access 2019, 7, 128125-128152. [CrossRef]

102. Alzoubi, I.; Delavar, M.R.; Mirzaei, F.; Arrabi, B.N. Prediction of environmental indicators in land leveling using artificial intelligence techniques. J. Environ. Health Sci. Eng. 2019, 16, 65-80. [CrossRef]

103. Brady, H.E. The challenge of big data and data science. Annu. Rev. Political Sci. 2019, 22, 297-323. [CrossRef]

104. Bui, K.H.; Jung, J.J. Computational negotiation-based edge analytics for smart objects. Inf. Sci. 2019, 480, 222-236. [CrossRef]

105. Cai, B.Y.; Alvarez, R.; Sit, M.; Duarte, F.; Ratti, C. Deep learning-based video system for accurate and real-time parking measurement. IEEE Internet Things J. 2019, 6, 7693-7701. [CrossRef]

106. Chen, M.; Miao, Y.; Jian, X.; Wang, X.; Humar, I. Cognitive-LPWAN: Towards intelligent wireless services in hybrid low power wide area networks. IEEE Trans. Green Commun. Netw. 2019, 3, 409-417. [CrossRef]

107. Chen, N.; Qiu, T.; Zhou, X.; Li, K.; Atiquzzaman, M. An intelligent robust networking mechanism for the internet of things. IEEE Commun. Mag. 2019, 57, 91-95. [CrossRef]

108. Cui, Q.; Wang, Y.; Chen, K.C.; Ni, W.; Lin, I.C.; Tao, X.; Zhang, P. Big data analytics and network calculus enabling intelligent management of autonomous vehicles in a smart city. IEEE Internet Things J. 2018, 6, 2021-2034. [CrossRef]

109. Desouza, K.C.; Dawson, G.S.; Chenok, D. Designing, developing, and deploying artificial intelligence systems: Lessons from and for the public sector. Bus. Horiz. 2019, 63, 205-213. [CrossRef]

110. Din, I.U.; Guizani, M.; Rodrigues, J.J.; Hassan, S.; Korotaev, V.V. Machine learning in the internet of things: Designed techniques for smart cities. Future Gener. Comput. Syst. 2019, 100, 826-843. [CrossRef]

111. Dong, Y.; Guo, S.; Liu, J.; Yang, Y. Energy-efficient fair cooperation fog computing in mobile edge networks for smart city. IEEE Internet Things J. 2019, 6, 7543-7554. [CrossRef]

112. Hariri, R.H.; Fredericks, E.M.; Bowers, K.M. Uncertainty in big data analytics: Survey, opportunities, and challenges. J. Big Data 2019, 6, 44. [CrossRef]

113. Ibrahim, M.R.; Haworth, J.; Cheng, T. Urban-i: From urban scenes to mapping slums, transport modes, and pedestrians in cities using deep learning and computer vision. Environ. Plan. B Urban Anal. City Sci. 2019. [CrossRef]

114. Iqbal, R.; Maniak, T.; Karyotis, C. Intelligent remote monitoring of parking spaces using licensed and unlicensed wireless technologies. IEEE Netw. 2019, 33, 23-29. [CrossRef]

115. Kundu, D. Blockchain and trust in a smart city. Environ. Urban. Asia 2019, 10, 31-43. [CrossRef]

116. Le, L.T.; Nguyen, H.; Dou, J.; Zhou, J. A comparative study of PSO-ANN, GA-ANN, ICA-ANN, and ABC-ANN in estimating the heating load of buildings' energy efficiency for smart city planning. Appl. Sci. 2019, 9, 2630. [CrossRef]

117. Leung, C.K.; Braun, P.; Cuzzocrea, A. AI-based sensor information fusion for supporting deep supervised learning. Sensors 2019, 19, 1345. [CrossRef] [PubMed] 
118. Li, L.; Shuang, Y.; Ma, Q.; Li, H.; Zhao, H.; Wei, M.; Liu, C.; Hao, C.; Qiu, C.W.; Cui, T.J. Intelligent metasurface imager and recognizer. Light Sci. Appl. 2019, 8, 1-9. [CrossRef]

119. Liu, N.; Li, L.; Hao, B.; Yang, L.; Hu, T.; Xue, T.; Wang, S. Modeling and simulation of robot inverse dynamics using LSTM-based deep learning algorithm for smart cities and factories. IEEE Access 2019, 7, 173989-173998. [CrossRef]

120. Lytras, M.D.; Chui, K.T.; Visvizi, A. Data analytics in smart healthcare: The recent developments and beyond. Appl. Sci. 2019, 9, 2812. [CrossRef]

121. Muhammad, K.; Lloret, J.; Baik, S.W. Intelligent and energy-efficient data prioritization in green smart cities: Current challenges and future directions. IEEE Commun. Mag. 2019, 57, 60-65. [CrossRef]

122. Noorbakhsh-Sabet, N.; Zand, R.; Zhang, Y.; Abedi, V. Artificial intelligence transforms the future of healthcare. Am. J. Med. 2019, 132, 795-801. [CrossRef]

123. Park, J.H.; Lee, S.; Yun, S.; Kim, H.; Kim, W.T. Dependable fire detection system with multifunctional artificial intelligence framework. Sensors 2019, 19, 2025. [CrossRef]

124. Ponce, H.; Gutiérrez, S. An indoor predicting climate conditions approach using Internet-of-Things and artificial hydrocarbon networks. Measurement 2019, 135, 170-179. [CrossRef]

125. Puri, V.; Jha, S.; Kumar, R.; Priyadarshini, I.; Abdel-Basset, M.; Elhoseny, M.; Long, H.V. A hybrid artificial intelligence and internet of things model for generation of renewable resource of energy. IEEE Access 2019, 7, 111181-111191. [CrossRef]

126. Rahman, M.A.; Rashid, M.M.; Hossain, M.S.; Hassanain, E.; Alhamid, M.F.; Guizani, M. Blockchain and IoT-based cognitive edge framework for sharing economy services in a smart city. IEEE Access 2019, 7, 18611-18621. [CrossRef]

127. Ruohomaa, H.; Salminen, V.; Kunttu, I. Towards a smart city concept in small cities. Technol. Innov. Manag. Rev. 2019, 9, 5-14. [CrossRef]

128. Sgantzos, K.; Grigg, I. Artificial intelligence implementations on the blockchain: Use cases and future applications. Future Internet 2019, 11, 170. [CrossRef]

129. Shi, J.; Liu, S.; Zhang, L.; Yang, B.; Shu, L.; Yang, Y.; Chai, Y. Smart textile-integrated microelectronic systems for wearable applications. Adv. Mater. 2019, 32, 1901958. [CrossRef]

130. Soomro, K.; Bhutta, M.N.; Khan, Z.; Tahir, M.A. Smart city big data analytics: An advanced review. Wiley Interdiscip. Rev. Data Min. Knowl. Discov. 2019, 9, e1319. [CrossRef]

131. Streitz, N. Beyond 'smart-only' cities: Redefining the 'smart-everything' paradigm. J. Ambient Intell. Humaniz. Comput. 2019, 10, 791-812. [CrossRef]

132. Syifa, M.; Kadavi, P.R.; Lee, C.W. An artificial intelligence application for post-earthquake damage mapping in Palu, Central Sulawesi, Indonesia. Sensors 2019, 19, 542. [CrossRef]

133. Wang, P.; Yao, J.; Wang, G.; Hao, F.; Shrestha, S.; Xue, B.; Peng, Y. Exploring the application of artificial intelligence technology for identification of water pollution characteristics and tracing the source of water quality pollutants. Sci. Total Environ. 2019, 693, 133440. [CrossRef]

134. Wei, N.; Li, C.; Peng, X.; Zeng, F.; Lu, X. Conventional models and artificial intelligence-based models for energy consumption forecasting: A review. J. Pet. Sci. Eng. 2019, 181, 106187. [CrossRef]

135. Wogu, I.A.; Misra, S.; Assibong, P.A.; Apeh, H.A.; Olu-Owolabi, F.E.; Awogu-Maduagwu, E.A. Artificial intelligence, smart class rooms and online education in the 21st century: Implications for human development. J. Cases Inf. Technol. 2018, 21, 66-79. [CrossRef]

136. Cortès, U.; Sànchez-Marrè, M.; Ceccaroni, L.; R-Roda, I.; Poch, M. Artificial intelligence and environmental decision support systems. Appl. Intell. 2000, 13, 77-91. [CrossRef]

137. Bennett, C.C.; Hauser, K. Artificial intelligence framework for simulating clinical decision-making: A Markov decision process approach. Artif. Intell. Med. 2013, 57, 9-19. [CrossRef] [PubMed]

138. Fernández, J.; Calavia, L.; Baladrón, C.; Aguiar, J.; Carro, B.; Sánchez-Esguevillas, A.; Alonso-López, J.; Smilansky, Z. An intelligent surveillance platform for large metropolitan areas with dense sensor deployment. Sensors 2013, 13, 7414-7442. [CrossRef] [PubMed]

139. Stefanelli, M. The socio-organizational age of artificial intelligence in medicine. Artif. Intell. Med. 2001, 23, 25-47. [CrossRef]

140. McArthur, D.; Lewis, M.; Bishary, M. The roles of artificial intelligence in education: Current progress and future prospects. J. Educ. Technol. 2005, 1, 42-80. [CrossRef] 
141. Pieters, W. Explanation and trust: What to tell the user in security and AI? Ethics Inf. Technol. 2011, 13, 53-64. [CrossRef]

142. Neuhauser, L.; Kreps, G.L.; Morrison, K.; Athanasoulis, M.; Kirienko, N.; Van Brunt, D. Using design science and artificial intelligence to improve health communication: ChronologyMD case example. Patient Educ. Couns. 2013, 92, 211-217. [CrossRef]

143. Roll, I.; Wylie, R. Evolution and revolution in artificial intelligence in education. Int. J. Artif. Intell. Education 2016, 26, 582-599. [CrossRef]

144. Castelli, M.; Sormani, R.; Trujillo, L.; Popovič, A. Predicting per capita violent crimes in urban areas: An artificial intelligence approach. J. Ambient Intell. Humaniz. Comput. 2017, 8, 29-36. [CrossRef]

145. Meena, N.K.; Parashar, S.; Swarnkar, A.; Gupta, N.; Niazi, K.R.; Bansal, R.C. Mobile power infrastructure planning and operational management for smart city applications. Energy Procedia 2017, 142, 2202-2207. [CrossRef]

146. Quan, S.J.; Park, J.; Economou, A.; Lee, S. Artificial intelligence-aided design: Smart design for sustainable city development. Environ. Plan. B Urban Anal. City Sci. 2019, 46, 1581-1599. [CrossRef]

147. Devedzic, V. Web Intelligence and artificial intelligence in education. Educ. Technol. Soc. 2004, 7, $29-39$.

148. Eldrandaly, K.A.; Abdel-Basset, M.; Abdel-Fatah, L. PTZ-surveillance coverage based on artificial intelligence for smart cities. Int. J. Inf. Manag. 2019, 49, 520-532. [CrossRef]

149. Altulyan, M.; Yao, L.; Kanhere, S.S.; Wang, X.; Huang, C. A unified framework for data integrity protection in people-centric smart cities. Multimed. Tools Appl. 2019, 79, 4989-5002. [CrossRef]

150. Yu, H.; Yang, Z.; Sinnott, R.O. Decentralized big data auditing for smart city environments leveraging blockchain technology. IEEE Access 2019, 7, 6288-6296. [CrossRef]

151. Bowman, S.; Easpaig, G.; Nic, B.; Fox, R. Virtually caring: A qualitative study of internet-based mental health services for LGBT young adults in rural Australia. Rural Remote Health 2020, 20, 31-38. [CrossRef]

152. Pence, H.E. Artificial intelligence in higher education: New wine in old wineskins? J. Educ. Technol. Syst. 2019, 48, 5-13. [CrossRef]

153. Guilherme, A. AI and education: The importance of teacher and student relations. AI Soc. 2019, 34, 47-54. [CrossRef]

154. The Conversation. COVID-19 Death Toll Estimated to Reach 3900 by Next Friday, According to AI Modelling. Available online: https:/theconversation.com/covid-19-death-toll-estimated-to-reach-3-900-by-next-fridayaccording-to-ai-modelling-133052 (accessed on 11 March 2020).

155. Lin, Y.P.; Petway, J.R.; Lien, W.Y.; Settele, J. Blockchain with artificial intelligence to efficiently manage water use under climate change. Environments 2018, 5, 34. [CrossRef]

156. Inclezan, D.; Prádanos, L.I. A critical view on smart cities and AI. J. Artif. Intell. Res. 2017, 60, 681-686. [CrossRef]

157. Zou, Y.; Zhang, S.; Min, Y. Exploring urban population forecasting and spatial distribution modelling with artificial intelligence technology. Comput. Model. Eng. Sci. 2019, 119, 295-310.

158. Rolnick, D.; Donti, P.L.; Kaack, L.H.; Kochanski, K.; Lacoste, A.; Sankaran, K.; Luccioni, A. Tackling climate change with machine learning. arXiv preprint arXiv 2019, arXiv:1906.05433.

159. O'Gorman, P.A.; Dwyer, J.G. Using machine learning to parameterize moist convection: Potential for modeling of climate, climate change, and extreme events. J. Adv. Model. Earth Syst. 2018, 10, 2548-2563. [CrossRef]

160. Dayal, K.; Deo, R.; Apan, A.A. Drought modelling based on artificial intelligence and neural network algorithms: A case study in Queensland, Australia. In Climate Change Adaptation in Pacific Countries; Springer: Singapore, 2017; pp. 177-198.

161. Khalifa, E. Smart cities: Opportunities, challenges, and security threats. J. Strateg. Innov. Sustain. 2019, 14, $79-88$.

162. Falco, G.; Viswanathan, A.; Caldera, C.; Shrobe, H. A master attack methodology for an AI-based automated attack planner for smart cities. IEEE Access 2018, 6, 48360-48373. [CrossRef]

163. Kankanamge, N.; Yigitcanlar, T.; Goonetilleke, A.; Kamruzzaman, M. Can volunteer crowdsourcing reduce disaster risk? A systematic review of the literature. Int. J. Disaster Risk Reduct. 2019, 35, 101097. [CrossRef]

164. Chatterjee, S.; Kar, A.K.; Gupta, M.P. Success of IoT in smart cities of India: An empirical analysis. Gov. Inf. Q. 2018, 35, 349-361. [CrossRef] 
165. Luo, X.; Tong, S.; Fang, Z.; Qu, Z. Frontiers: Machines vs. humans: The impact of artificial intelligence chatbot disclosure on customer purchases. Mark. Sci. 2019, 38, 937-947. [CrossRef]

166. Yigitcanlar, T. Smart cities: An effective urban development and management model? Aust. Plan. 2015, 52, 27-34. [CrossRef]

167. Rotta, M.J.; Sell, D.; Pacheco, R.C.; Yigitcanlar, T. Digital commons and citizen coproduction in smart cities: Assessment of Brazilian municipal e-government platforms. Energies 2019, 12, 2813. [CrossRef]

168. Yigitcanlar, T. Smart city policies revisited: Considerations for a truly smart and sustainable urbanism practice. World Technopolis Rev. 2018, 7, 97-112.

169. Rjab, A.B.; Mellouli, S. Smart cities in the era of artificial intelligence and internet of things: Literature review from 1990 to 2017. In Proceedings of the 19th Annual International Conference on Digital Government Research: Governance in the Data Age, Delft, The Netherlands, 30 May-1 June 2018; pp. 1-10.

170. Friedman, B.; Hendry, D.G. Value Sensitive Design: Shaping Technology with Moral Imagination; MIT Press: Cambridge, MA, USA, 2019.

171. LSE. Why Low Trust in Government May Mean Americans Don't Want Anything Done about Inequality. Available online: https://blogs.lse.ac.uk/usappblog/2019/12/23/why-low-trust-in-government-may-meanamericans-dont-want-anything-done-about-inequality (accessed on 20 February 2020).

172. Morishita, L.; van Zyl, D. Exploring the significance of earning a social license to operate in an urban setting. Geo-Resour. Environ. Eng. 2017, 2, 265-270. [CrossRef]

173. Yuttapongsontorn, N.; Desouza, K.C.; Braganza, A. Complexities of large-scale technology project failure: A forensic analysis of the Seattle popular monorail authority. Public Perform. Manag. Rev. 2008, 31, 443-478. [CrossRef]

174. Mergel, I.; Desouza, K.C. Implementing open innovation in the public sector: The case of Challenge. gov. Public Adm. Rev. 2013, 73, 882-890. [CrossRef]

175. Desouza, K.C.; Bhagwatwar, A. Technology-enabled participatory platforms for civic engagement: The case of US cities. J. Urban Technol. 2014, 21, 25-50. [CrossRef]

176. Liu, Y. Research on the evaluation of urban open data. World J. Eng. Technol. 2017, 5, 122-134. [CrossRef]

177. Perng, S.Y.; Kitchin, R.; Mac Donncha, D. Hackathons, entrepreneurial life and the making of smart cities. Geoforum 2018, 97, 189-197. [CrossRef]

178. CNN. Artist Uses 99 Phones to Trick Google into Traffic Jam Alert. Available online: https://us.cnn.com/ style/article/artist-google-traffic-jam-alert-trick-scli-intl/index.html (accessed on 20 February 2020).

179. Desouza, K.C. Agile Information Systems: Conceptualization, Construction, and Management; Routledge: Abingdon upon Thames, UK, 2006.

180. Watson, R.T.; Kunene, K.N.; Islam, M.S. Frugal information systems (IS). Inf. Technol. Dev. 2013, 19 , $176-187$. [CrossRef]

181. Planetizen. Our Fragile Emerging Megacities: A Focus on Resilience. Available online: https://www. planetizen.com/node/67338 (accessed on 19 February 2020).

182. Purao, S.R.; Desouza, K.C.; Becker, J. Investigating failures in large-scale public sector projects with sentiment analysis. e-Serv. J. 2012, 8, 84-105. [CrossRef]

183. Desouza, K.C.; Hunter, M.; Yigitcanlar, T. Under the hood: A look at techno-centric smart city development. Public Manag. 2019, 12, 30-35.

184. Krishnamurthy, R.; Smith, K.L.; Desouza, K.C. Urban informatics: Critical data and technology considerations. In Seeing Cities Through Big Data; Springer: Singapore, 2017; pp. 163-188.

185. Wired. A Deep Flaw in Your Car Lets Hackers Shut Down Safety Features. Available online: https: //www.wired.com/story/car-hack-shut-down-safety-features (accessed on 14 February 2020).

186. BBC. China Coronavirus: Misinformation Spreads Online About Origin and Scale. Available online: https://www.bbc.com/news/blogs-trending-51271037 (accessed on 20 February 2020).

187. BBC. Burned to Death Because of a Rumour on WhatsApp. Available online: https://www.bbc.com/news/ world-latin-america-46145986 (accessed on 30 December 2019).

188. Gherhes, V.; Obrad, C. Technical and humanities students' perspectives on the development and sustainability of artificial intelligence (AI). Sustainability 2018, 10, 3066. [CrossRef]

189. The Conversation. Australian Police are Using the Clearview AI Facial Recognition System with No Accountability. Available online: https:/theconversation.com/australian-police-are-using-the-clearview-aifacial-recognition-system-with-no-accountability-132667 (accessed on 11 March 2020). 
190. The Conversation. Airlines Take no Chances with Our Safety. And Neither Should Artificial Intelligence. Available online: https://theconversation.com/airlines-take-no-chances-with-our-safety-and-neither-shouldartificial-intelligence-132580 (accessed on 11 March 2020).

191. The Verge. IBM's Watson Gave Unsafe Recommendations for Treating Cancer. Available online: https://www. theverge.com/2018/7/26/17619382/ibms-watson-cancer-ai-healthcare-science (accessed on 12 March 2020).

192. NTSB. Preliminary Report Released for Crash Involving Pedestrian, Uber Technologies, Inc., Test Vehicle. Available online: https://www.ntsb.gov/news/press-releases/Pages/NR20180524.aspx (accessed on 13 March 2020).

193. The Conversation. Microsoft's Racist Chatbot Tay Highlights How Far AI is from being Truly Intelligent. Available online: https://theconversation.com/microsofts-racist-chatbot-tay-highlights-how-far-ai-is-frombeing-truly-intelligent-56881 (accessed on 13 March 2020).

194. Forbes. Is Artificial Intelligence Dangerous? 6 AI Risks Everyone Should Know About. Available online: https://www.forbes.com/sites/bernardmarr/2018/11/19/is-artificial-intelligence-dangerous-6-ai-riskseveryone-should-know-about/\#65ee8ba22404 (accessed on 13 March 2020).

195. The Conversation. To Protect us from the Risks of Advanced Artificial Intelligence, We Need to Act Now. Available online: https://theconversation.com/to-protect-us-from-the-risks-of-advanced-artificialintelligence-we-need-to-act-now-107615 (accessed on 13 March 2020).

196. Medium. Summary of EU White Paper on Artificial Intelligence: A European Approach to Excellence and Trust. Available online: https://medium.com/@tibastar/summary-of-eu-white-paper-on-artificialintelligence-a-european-approach-to-excellence-and-trust-e04a1a018b5 (accessed on 11 March 2020).

197. EU. On Artificial Intelligence: A European Approach to Excellence and Trust. Available online: https: //ec.europa.eu/info/sites/info/files/commission-white-paper-artificial-intelligence-feb2020_en.pdf (accessed on 11 March 2020).

198. The Guardian. Elon Musk: Regulate AI to Combat 'Existential Threat' before It's too Late. Available online: https://www.theguardian.com/technology/2017/jul/17/elon-musk-regulation-ai-combat-existentialthreat-tesla-spacex-ceo (accessed on 13 March 2020).

199. Schleiger, E.; Hajkowicz, S. Artificial Intelligence in Australia Needs to Get Ethical, So We Have a Plan. Available online: https://www.themandarin.com.au/107060-artificial-intelligence-in-australia-needs-to-getethical-so-we-have-a-plan (accessed on 15 March 2020).

200. Nica, E.; Manole, C.; Stan, C.I. A laborless society? How highly automated environments and breakthroughs in artificial intelligence bring about innovative kinds of skills and employment disruptions, altering the nature of business process and affecting the path of economic growth. J. Self-Gov. Manag. Econ. 2018, 6, 25-30.

201. Gunkel, D.J. The Machine Question: Critical Perspectives on AI, Robots, and Ethics; MIT Press: Cambridge, MA, USA, 2012.

202. Makridakis, S. The forthcoming artificial intelligence (AI) revolution: Its impact on society and firms. Futures 2017, 90, 46-60. [CrossRef]

203. Sheikhnejad, Y.; Yigitcanlar, T. Scientific landscape of sustainable urban and rural areas research: A systematic scientometric analysis. Sustainability 2020, 12, 1293. [CrossRef]

204. Smashing Magazine. How AI is Helping Solve Climate Change. Available online: https://www. smashingmagazine.com/2019/09/ai-climate-change (accessed on 11 March 2020).

205. Yigitcanlar, T.; Vella, K.; Desouza, K.; Butler, L.; Kankanamge, N. Smart City or Not? Now You Can See How Yours Compares. Available online: https://eprints.qut.edu.au/180751/ (accessed on 15 March 2020).

(C) 2020 by the authors. Licensee MDPI, Basel, Switzerland. This article is an open access article distributed under the terms and conditions of the Creative Commons Attribution (CC BY) license (http://creativecommons.org/licenses/by/4.0/). 